\title{
ENTREPRENEURIAL IMAGINATIVENESS IN NEW VENTURE IDEATION
}

\author{
ALEXANDER S. KIER \\ Washington State University Vancouver \\ JEFFERY S. MCMULLEN \\ Indiana University
}

\begin{abstract}
Although theories of entrepreneurial action regularly acknowledge the importance of imagination, the ability is rarely defined or measured, and thus effectively treated as uniform in degree and type. Using a creative problem-solving lens, we identify and measure three different cognitive skills—creative, social, and practical imaginativeness-that vary across individuals. Each skill combines the ability of imagination with the knowledge needed to mentally simulate various task-related scenarios used in generating and selecting ideas for new value creation. We then conduct a quasi-experiment to examine each skill's relative effect on new venture ideation. We find that the three imaginativeness skills vary across individuals and that they predict new venture idea quantity and quality differently over and above the effects of motivation, knowledge, and experience. We conclude with implications for theory development in entrepreneurship and creative problem-solving.
\end{abstract}

Since the turn of the century, models of entrepreneurial action have abounded in both theory (e.g., Baker \& Nelson, 2005; McMullen \& Shepherd, 2006; Sarasvathy, 2001; Shane \& Venkataraman, 2000) and practice (Brown, 2009; Osterwalder \& Pigneur, 2010; Ries, 2011). Each has sought to explain how individuals transform ideas into opportunities through action by slowly reorienting scholarly attention upstream from firm performance to opportunity, to idea, and to the source of those ideas (e.g., Vogel, 2016). Because ideas "constitute the lifeblood for firms in generating new products or services, new business models, new processes, and bringing about general organizational or strategic change" (van den Ende, Frederiksen, \& Prencipe, 2015: 482), research on their origins is needed to explain the micro foundations of both entrepreneurial action (Shepherd, 2015) and "the early stages of creation of new economic activities, which is arguably where entrepreneurship

We would like to thank Dean Shepherd, Donald Kuratko, Chris Berry, Keith Hmieleski, Denis Grégoire, Todd Chiles, and Regan Stevenson for their invaluable feedback on earlier drafts of this manuscript as well as three anonymous reviewers for their support and developmental comments. Prior versions of this manuscript were presented at the 2017 Babson College Entrepreneurship Research Conference and published in the 2017 edition of Frontiers of Entrepreneurship Research BCERC Proceedings. research can make its more distinctive contributions to the broader fields of economic and organizational studies" (Davidsson, 2015: 676). Accordingly, this study examines "new venture ideation," defined as the capability to generate and select new venture ideas.

The creation of new ventures is a process by which "entrepreneurs come to imagine the opportunity for novel ventures" (Cornelissen \& Clarke, 2010: 539). They use their imaginations to create new ideas (Chiles, Tuggle, McMullen, Bierman, \& Greening, 2010) that entrepreneurial action either proves to be opportunities for new ventures (Davidsson, 2003, 2015; Dimov, 2007a, 2011; Vogel, 2016) or reveals to be mistaken beliefs (Shepherd, Haynie, \& McMullen, 2012). Because "all great ventures begin with imagination" (Seelig, 2015: 56) and opportunities are "ultimately determined through creative imagination and social skill of the entrepreneur" (Suddaby, Bruton, \& Si, 2015: 3), imagination is critical to new venture ideation.

Despite its espoused importance to entrepreneurial action, imagination is rarely examined, much less defined or measured by entrepreneurship scholars. Such neglect is also true of creative problem-solving researchers who have long sought to explain the creativity behind ideation as a function of attitude, knowledge, evaluation, and imagination (Isaksen, Dorval, \& Treffinger, 2011). In these models, "attitude" refers 
primarily to motivation and manifests as effort, "knowledge" is embodied by general human capital, and "evaluation" often refers to the judgment informed by experience. Though "imagination" is commonly recognized as the final pillar, the creativity literature typically conceptualizes it as an ability or mindset frequently manipulated but rarely measured (Puccio, Mance, Switalski, \& Reali, 2012).

In this study, we examine imagination's role in new venture ideation through a creative problemsolving lens and use of a quasi-experimental design. By doing so, we heed the words of Miller and Miller (2017: 7) that "researching entrepreneurial imagination at the cognitive level may be worthy of experimental study." We had 506 individuals from the general working population with varying entrepreneurial experience and randomly distributed across the United States (a) generate as many new venture ideas as possible, based on a description and diagram of new technology, and (b) select their best idea and write a short description of that idea. In addition, we directly measured their motivation, knowledge, and experience, and indirectly measured their imagination via "imaginativeness" - a cognitive skill that combines the ability of imagination with the knowledge needed to mentally simulate various task-related scenarios in entrepreneurship. To do so, we developed a measure of three forms of entrepreneurial imaginativeness used in new value creationcreative, social, and practical-and demonstrated the scale's predictive validity for new venture idea generation and selection (Perry-Smith \& Mannucci, 2017) over and above the effects of motivation, knowledge, and experience. Thus, our findings show that (a) entrepreneurial imaginativeness is measurable, (b) its three forms vary across individuals, (c) these three forms of imaginativeness predict new venture idea quantity and quality differently, (d) they do so over and above the other more commonly examined predictors of ideation, and (e) these forms of entrepreneurial imaginativeness are more important (have greater relative weight) in predicting new venture ideation than the usual suspects.

In addition to enhancing the explanatory power of creative problem-solving models in new venture ideation, our findings suggest a possible need to refine entrepreneurship theory. Although explanations of new venture ideation are relatively sparse in the academic literature, prior research has emphasized the role of knowledge (Shane, 2000), experience (Davidsson \& Honig, 2003), motivation (McMullen \& Shepherd, 2006), and imagination (Cornelissen \& Clarke, 2010) in opportunity recognition, one step removed from ideation (Dimov, 2007a; Vogel, 2016). Most of these models of entrepreneurial action assume the existence and ubiquity of imagination, but, even if the ability of imagination is evenly distributed throughout the population, its manifestation as various forms of entrepreneurial imaginativeness skillscreative, social, and practical-may not be. Because we find that these forms of imaginativeness are independent of one another, current theories of entrepreneurial action may be limited to individuals high in all three, require teams of individuals to compensate for each other's shortcomings, or require particular types of knowledge or experience to compensate for either an individual's or a team's lack of various forms of imaginativeness. Regardless, extant entrepreneurship theory may require greater specification of imagination's assumed role in explaining entrepreneurial action.

The rest of the paper proceeds as follows. First, we examine the concept of new venture ideation as a form of creative problem-solving. Then, we explore how entrepreneurial imaginativeness manifests in three different forms-creative, social, and practical-to hypothesize their effects on new venture ideation. We then test our hypotheses empirically by employing a quasi-experimental design on those with and without entrepreneurial experience as they generate and select new venture ideas based on new technology. We conclude with a discussion of our findings, using them to highlight future research opportunities concerning the role of imaginativeness in entrepreneurship.

\section{THEORY AND HYPOTHESES}

\section{New Venture Ideation}

"Ideation" refers to the generation of ideas, especially novel ideas, for artifact design (McCall, 2010: 11), creating, sourcing, or deriving ideas for new products, services, or business models (Flynn, Dooley, O'Sullivan, \& Cormican, 2003), or the process of generating, developing, and testing ideas that may lead to solutions (Brown, 2008). The focus of this study is on two subtasks that make up ideation: (1) generating ideas, and (2) selecting ideas (Basadur, Graen, \& Green, 1982; Perry-Smith \& Mannucci, 2017). Generating ideas represents the diverging aspect of the creative problem-solving process, whereas selecting ideas represents the converging aspect of the process (Basadur et al., 1982; Gielnik, Frese, Graf, \& Kampschulte, 2012).

Although the term ideation may be relatively new to the entrepreneurship literature, its origins stem from decades of work in creative problem-solving. 
"Creative problem-solving" refers to "any activity during which an individual, team, or organization attempts to produce novel solutions to ill-defined problems" (Puccio, 1999: 171). Although many theories of creative problem-solving exist, most identify similar predictors of success. Amabile (1983) outlined three components of creativity: (1) domainrelevant skills, which include knowledge about the domain; (2) creativity-relevant skills, which depend on experience in idea generation; and (3) task motivation, which includes attitudes toward the task. Runco and Chand (1995) proposed a similar model that comprised a set of skills-problem finding, ideation, and evaluation-all moderated by knowledge and motivation. Perry-Smith and Shalley (2003) posited that creativity occurs through domain-relevant knowledge, technical expertise and experience, and the ability to think creatively (i.e., generate alternatives, think outside the box, suspend judgment, etc.). Basadur, Graen, and Wakabayashi (1990) noted that creative problemsolving is a product of knowledge, imagination, and judgment, wherein knowledge is transformed by one's imagination into various combinations, points of view, or ideas, and judgment is used to select the most appropriate idea for further development. Finally, mathematician and creativity researcher Ruth Noller proposed that creativity is a function of attitude, knowledge, evaluation, and imagination (Isaksen et al., 2011), with Runco (2004) noting that motivation, knowledge, and imagination each play a significant role in creative cognition. Thus, there is a general consensus among creativity researchers that creative problem-solving involves four main elements: knowledge, experience, motivation, and imagination.

In this article, we focus on "new venture ideation"- the generation and selection of ideas for the creation of a new venture. As a subclass of ideation, new venture ideation represents one end of a continuum that becomes increasingly social and more complex as one moves from ideation to new venture ideation (Gemmell, Boland, \& Kolb, 2012). Like ideation, new venture ideation exhibits a concern with novelty, but it also involves usefulness as customers validate the entrepreneur's expected value of his or her idea, and entrepreneurs imagine negotiating a production process involving numerous stakeholders merely to offer a novel and useful idea to customers who may reject it. Thus, problems in multiple domains must be solved for new ventures to succeed. Entrepreneurs need a new product, a new market, and/or a new strategy to connect the two both efficiently and appropriately, but, given that they have yet to take action, there may be no feedback upon which to base their judgments, leaving entrepreneurs to make decisions based on what might happen in response to their hypothetical actions. Such decision-making about the novelty and usefulness of ideas given an inherently uncertain future requires judgment, but this judgment partly involves speculation, which is an act of the imagination (Weick, 1989).

\section{Imagination}

"Imagination" is the ability to "make mental images of things that may not exist in real life" (Collins English Dictionary \& Thesaurus, 2006), to "conjure up images, stories, and projections of things not currently present and the use of those projections for entertaining the self, planning for the future, and performing other basic tasks" (Taylor, Pham, Rivkin, \& Armor, 1998: 429). Imagination encompasses not only notions of imagery (Thomas, 1999), but also notions of mental simulation (Kahneman \& Tversky, 1982). Mental simulation relies on imagination's cognitive ability to anticipate physical and social environments, conceive of strategies and tactics that lead to the achievement of goals, motives, and purpose, and prepare for different behavioral responses (Gaglio, 2004). Thus, Jean-Paul Sartre noted that imagination is not limited to visualization and the purely mental states that provide its equivalents; instead, imagination includes human engagement with a range of external objects and events (Hopkins, 2016).

Mental simulation and therefore imagination can involve replaying events that have already occurred, like those of an investor pitch; constructing hypothetical scenarios, such as what to do if technology fails during an investor pitch; and combining real and hypothetical events, such as inserting what one should have said during an investor pitch (Taylor \& Schneider, 1989; Taylor et al., 1998). As a result of this cognitive flexibility, Gaglio (2004) argued that, when entrepreneurs imagine (i.e., mentally simulate), they can generate multiple competing hypotheses, break means-end frameworks, and find innovative market opportunities.

Imagination is often used to explain the generation of new combinations that are necessary for novel creation. For example, Cornelissen and Clarke (2010) claimed that the ability to rearrange or blend words creatively in the form of analogies or metaphors allows entrepreneurs to imagine future 
opportunities. Chiles and colleagues (2010) argued that entrepreneurs use their active imaginations to create new ideas, and Grégoire and Shepherd (2012) suggested that entrepreneurs use structural alignment cognitive processes to find or imagine promising opportunities. These examples, along with many others outlined in Table 1, illustrate that most models of entrepreneurial action treat imagination as an essential but latent construct that is rarely defined, much less measured. More often than not, readers are left to infer their own meaning of the term and presume its effect on entrepreneurial action. Yet, extant research typically implies that imagination is driving creative problem-solving and, by extension, entrepreneurial action.

\section{Imaginativeness}

We propose that, when the cognitive ability of imagination is mixed with the knowledge needed to mentally simulate various task-related scenarios in entrepreneurship, such as innovation, communication, and administration, it becomes the measurable skills of creative, social, and practical imaginativeness used to generate and select new venture ideas. Schumpeter (1942), for example, highlighted the importance of innovation in which entrepreneurship is seen as a recombination of resources that disrupts through "creative destruction" the economy's equilibrium. Imaginativeness facilitates this creative destruction by allowing the entrepreneur to envision what could be. This form of imaginativeness is used for creativity (LeBoutillier \& Marks, 2003), innovation (Liedtka, 2014; van den Ende et al., 2015), new product development (Dahl, Chattopadhyay, \& Gorn, 1999, 2001), or idea production (De Bono, 1992).

Other scholars view entrepreneurship mainly as an act of communication and cooperation (Chiles et al., 2010; McMullen, 2010, 2015), where entrepreneurs must learn not only to understand others' wants and needs, effectively discovering demand (Hayek, 1945; Kirzner, 1973), but also to educate, sell, or persuade others to try the new supply the entrepreneur has to offer (Sarasvathy, 2001). Thus, entrepreneurs must imagine who, how, and what might be impacted by the innovation they are contemplating (McMullen, 2010). Because people cannot directly observe motives, they must use their imaginativeness to make social inferences about others' beliefs, desires, or intent when they are ascribing meaning to their behavior (Bagozzi, Verbeke, Dietvorst, Belschak, van den Berg, \& Rietdijk, 2013;
Frith \& Frith, 2006, 2008). Thus, discerning this future and cajoling others to co-create along the way requires social imaginativeness to interpret and make sense of what is occurring or could occur with various stakeholders.

Finally, entrepreneurship is also viewed as an act of administration (Lazear, 2004; Lechmann \& Schnabel, 2014; Wagner, 2003) and judgment (Klein, 2008; Knight, 1921; McMullen \& Shepherd, 2006), wherein the entrepreneur is a manager or superintendent, an organizer and coordinator of economic resources, and an employer of factors of production (Carland, Hoy, Boulton, \& Carland, 1984; Hébert \& Link, 1989). Imaginativeness is thus needed in the practical sense to predict, project, or forecast what will likely be in the future. This is the form of imaginativeness that many associate with everyday choice and reason (Johnson, 1987; Shackle, 1979).

Together, these acts of innovation, communication, and administration point to three primary forms of entrepreneurial imaginativeness (creative, social, and practical) that are structurally analogous to Sternberg's (1985) triarchic theory of intelligence, which outlines three components of human intelligence (contextual, experiential, and componential). There may be other forms of imaginativeness that are relevant to entrepreneurial action, but these three are commonly considered by functionalist theories of entrepreneurship to be necessary for the creation of new value (Barreto, 1989; Casson, 1982; Hébert \& Link, 1988; Mitchell et al., 2007). Creative imaginativeness facilitates product innovation by helping entrepreneurs anticipate the effects of introducing new knowledge to the price system via new products or services (e.g., McMullen \& Dimov, 2013; Schumpeter, 1934). Social imaginativeness facilitates communication and market responsiveness by helping entrepreneurs anticipate the effects of introducing new exchanges to the price system (e.g., Chiles et al., 2010; Kirzner, 1979). Finally, practical imaginativeness facilitates administration by helping entrepreneurs contemplate the feasibility and desirability of introducing new structures of production to the price system via organizing and project management (e.g., Gartner, 2016; Say, 1880). In the paragraphs that follow, we further elaborate on each form of imaginativeness and how it influences new venture idea quantity and quality.

Creative imaginativeness and new venture idea quantity. "Creative imaginativeness" is the cognitive skill to envision something that cannot be or is not currently being observed for the purposes of 


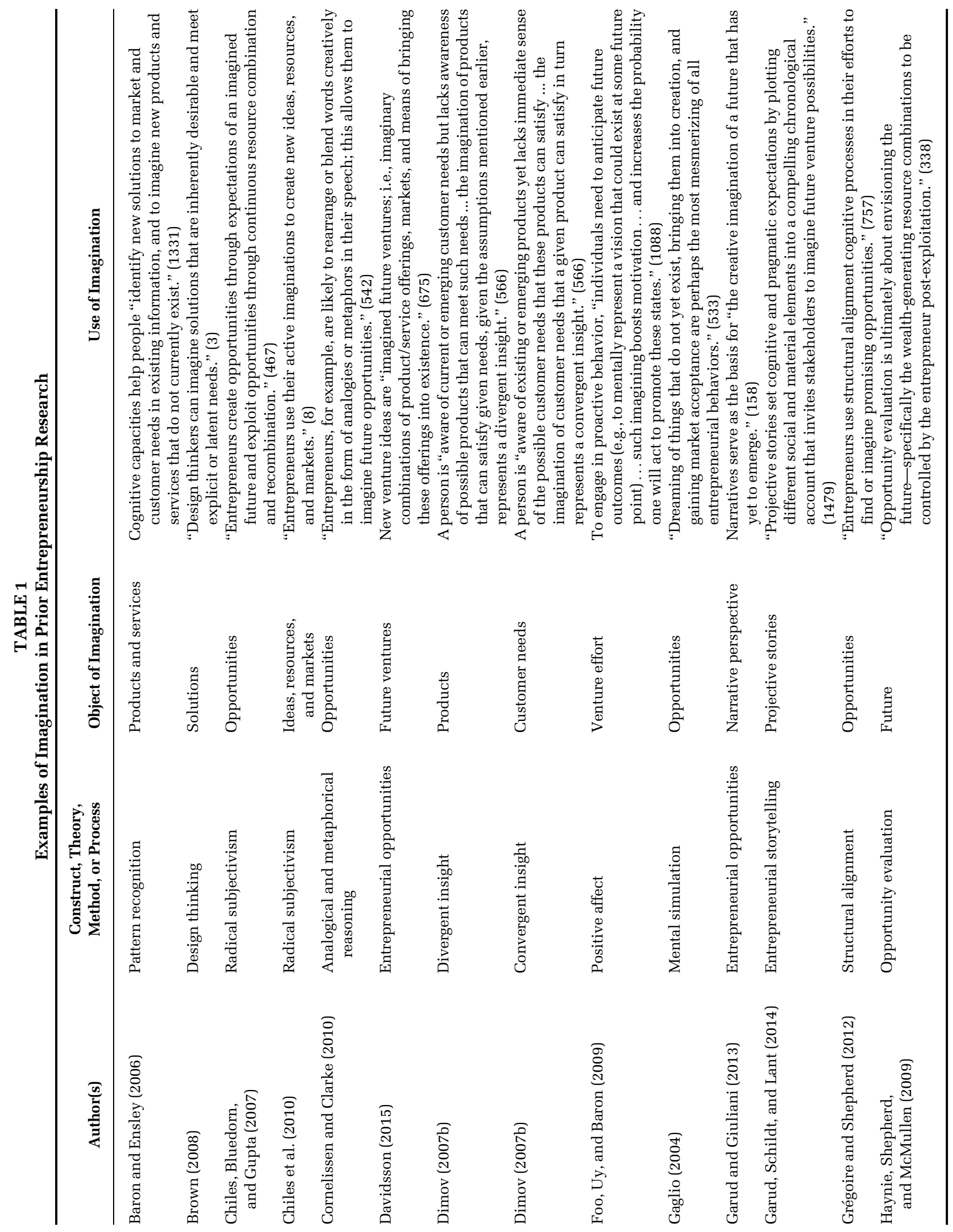




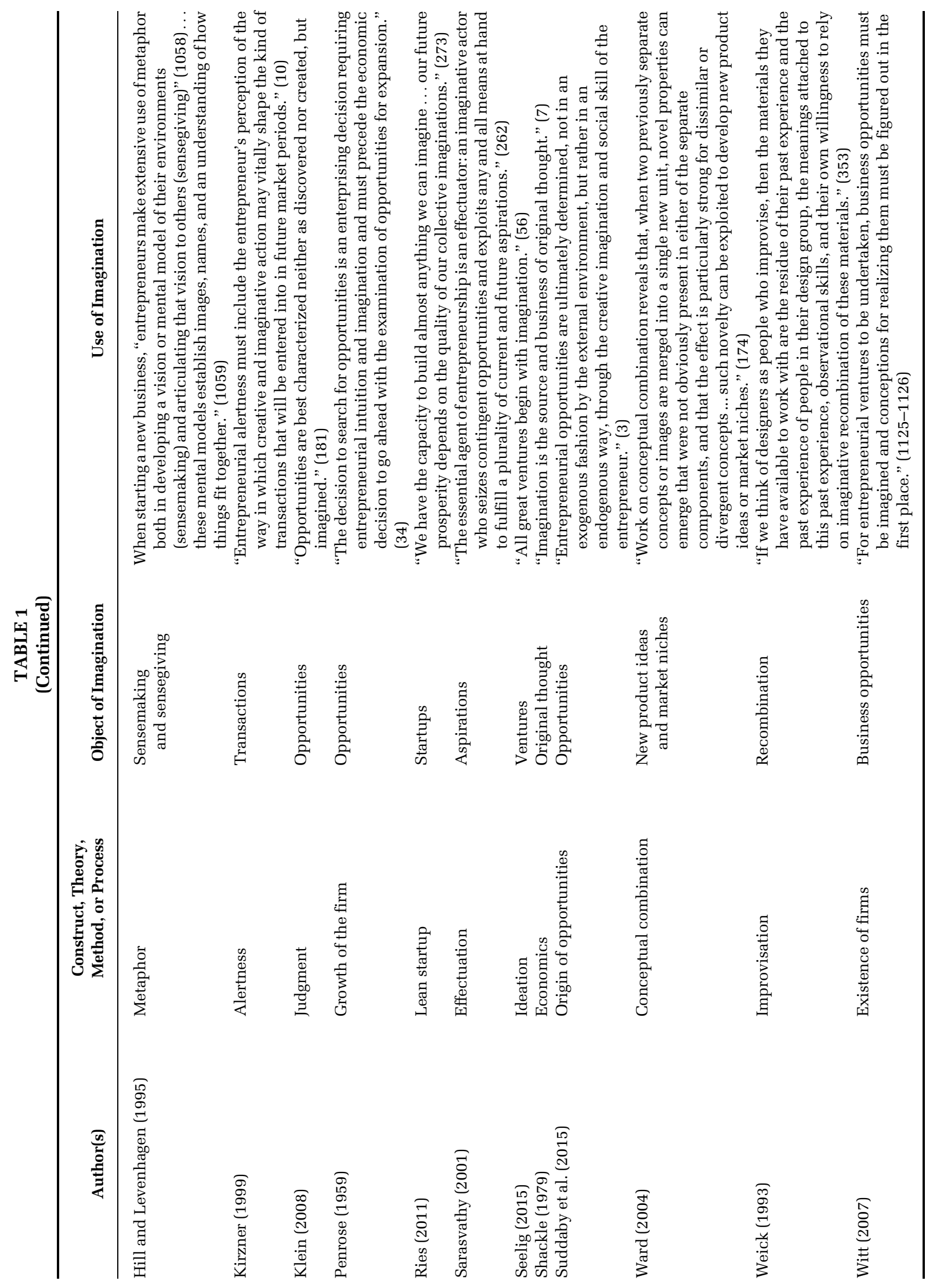


novel, original, artistic, or innovative creation. Individuals possessing creative imaginativeness make novel connections to form new means-ends relationships (Eckhardt \& Shane, 2003). They are unafraid to take a fresh approach to problems or situations.

Imaginativeness is a tool separate and distinct from creativity (Vygotsky, 1990; also see Kind, 2016). For example, Kant noted that imagination enables creativity through free, non-rule governed activity by which people achieve new structure in their experience and can remold existing patterns to generate novel meaning (Johnson, 1987). Similarly, Vygotsky (1990) suggested that imagination serves as the basis of all creative activity. For example, creativity is often defined as the "production of novel and useful ideas" (Amabile, 1988: 126; Amabile, Barsade, Mueller, \& Staw, 2005: 368; Amabile, Conti, Coon, Lazenby, \& Herron, 1996: 1155), a definition widely accepted by the literature (James, Brodersen, \& Eisenberg, 2004; Paulus \& Nijstad, 2003; PerrySmith \& Shalley, 2003; Sternberg \& Lubart, 1999). In this form, creativity-or, more precisely, creative performance (Amabile, 1983)—is conceptualized as a behavioral outcome and but one of many possible outputs to the input of imagination.

Although creative imaginativeness is an antecedent or driver of creative outcomes, it can also lead to non-creative outcomes (i.e., outcomes that are not novel and useful). For example, one can be imaginative without being creative (e.g., unnecessary worrying, fear of the unknown, etc.). Empirically, however, the two are closely related. For example, imagining ability (Campos \& González, 1993a, 1993b, 1995; Campos \& Perez, 1989; González, Campos, \& Pérez, 1997; Juhasz, 1972), visual imagery (Arieti, 1976; Koestler, 1964; McKellar, 1957; Parrott \& Strongman, 1985; Schmeidler, 1965), concrete imagery (Paivio, 1971, 1975), and vividness of imagery (Forisha, 1978; Khatena, 1975; Richardson, 1969; Shaw \& DeMers, 1986) have all been shown to relate positively to creativity. Indeed, meta-analysis reveals that mental imagery is positively associated with performance on creative thinking tasks (LeBoutillier \& Marks, 2003).

Like others (Kind, 2016; Vygotsky, 1990), we posit that creative imaginativeness fuels the innovative new combinations of resources that Schumpeter (1934) saw as the function of the entrepreneur and source of economic development. These include (a) product innovation-introduction of a new good or new quality of a good; (b) process innovationintroduction of a new method of production; (c) market innovation-opening a new market; (d) input innovation-conquest of a new source of supply of raw material or intermediate input; and (e) organizational innovation-carrying out of a new organization of industry. Not only can the amount of novelty vary within each of these forms of innovation, but also new ventures can vary in how many of these forms of innovation they contain. The entrepreneur may (a) innovate to introduce a product that is new to the world, (b) use the product innovation to solve problems that customers may not even know they had, and (c) overcome significant resource coordination issues to do so. This archetypal entrepreneurial action is often associated with Steve Jobs (Isaacson, 2011) or Elon Musk (Vance, 2015), individuals renowned for reshaping entire industries in Schumpeterian fashion. For example, Musk's Tesla Motors or SpaceX are new ventures that would certainly qualify as strong form entrepreneurship because of their novelty along multiple dimensions of new value creation. As a result, creative imaginativeness may play a more prominent role in the generation and selection of ideas for radically innovative new ventures such as Tesla Motors than for incrementally innovative or imitative new ventures such as a new McDonalds franchise.

Creative imaginativeness supports new venture idea quantity by enabling individuals to generate alternatives to a given problem. Through alternatives, individuals seek to generate appropriate solutions to a problematic situation to maximize the likelihood that the most effective response will be among those generated (D'Zurilla \& Goldfried, 1971). Thus, creative imaginativeness supports "brainstorming"-generating as many ideas as possible without passing judgment on their value, acceptability, or appropriateness (Osborn, 1963)—and "divergent thinking"-generating multiple, novel, and original ideas (Basadur et al., 1982; Brophy, 1998; Cropley, 2006; Gielnik et al., 2012; Mumford, Mobley, Reiter-Palmon, Uhlman, \& Doares, 1991); essentially, "letting one's imagination run loose" (D’Zurilla \& Goldfried, 1971: 115). When generating alternatives, people rely on their creative imaginativeness to form mental images of potential solutions and try to make connections between seemingly unrelated pieces of information (Vygotsky, 1990). These novel connections of old elements lead to what advertising executive, Jake Foster, defines as an idea: "Nothing more nor less than new combination of old elements" (Foster, 2007: 4). Hence, entrepreneurship researchers have theorized that creativity is required to generate novel and useful ideas for 
business ventures (Ward, 2004) and that this outcome occurs through a process of "bisociation" (Smith \& Di Gregorio, 2002; see also Koestler, 1964) in which creative imaginativeness combines old elements into new possibilities (Chiles et al., 2010; Weick, 2006). In addition, researchers have demonstrated empirically that creative personalities are more likely to identify business opportunities (Shane \& Nicolaou, 2015) and that creativity has a direct effect on the generation of original business ideas (Gielnik et al., 2012). Thus, we hypothesize:

Hypothesis 1. Creative imaginativeness positively relates to new venture idea quantity.

Social imaginativeness and new venture idea quantity. "Social imaginativeness" is a cognitive skill with which one envisions something that cannot be or is not currently being observed for the purposes of taking the perspective of others, seeing and feeling the world from another's frame of reference, or reading the desires, intentions, beliefs, and emotions of others. It is rooted primarily in the psychological constructs of empathy and perspective taking as well as the theory of mind literature from cognitive neuroscience.

"Empathy" refers to an "imaginative transposing of oneself into the thinking, feeling, and acting of another" (Norman \& Ainsworth, 1954: 53), perceiving the world correctly from another person's frame of reference (Grossman, 1951), taking another's role, placing oneself in another's shoes, and perceiving the situation from another's perspective (Cottrell \& Dymond, 1949). "Perspective taking," by contrast, is usually described as the cognitive form of empathy, or the "cognitive capacity to consider the world from other viewpoints" (Galinsky, Maddux, Gilin, \& White, 2008: 378). Though it shares empathy's mental simulation of another's viewpoint, perspective taking lacks the affect considered essential to many conceptions of empathy. For example, Galinsky and colleagues (2008) defined empathy as an "other focused emotional response that allows one person to affectively connect with another" (Galinsky et al., 2008: 378). Finally, "theory of mind" refers to the "ability to read the desires, intentions, and beliefs of other people" (Frith \& Frith, 2008: 54). Like perspective taking and empathy, theory of mind appears to rely on imagination to understand other people's mental states (Goldman, 2006), which in turn allows an individual to anticipate the behavior and reactions of others (Davis, 1983; Frith \& Frith, 2006); however, theory of mind tends to be more concerned with the human ability to attribute mental states to others (Völlm et al., 2006) than with individual variance in this mindreading skill.

Together, empathy, perspective taking, and theory of mind are essential to understanding, communicating, cooperating, and even competing with others. Because social imaginativeness offers a common denominator to each, those with social imaginativeness can not only discern what customers need and want, but can also determine who other stakeholders might be, why they might be interested in a particular new venture idea, and how to negotiate their involvement, be they investors, employees, government officials, or others (McMullen, 2010, 2015). Because they enable the communication and understanding that facilitates exchange, these social skills have been identified as integral to successful entrepreneurial action (Fligstein, 1997; Miller, Grimes, McMullen, \& Vogus, 2012).

Social imaginativeness contributes to new venture idea quantity by enabling individuals to understand the wants and needs of others. When entrepreneurs take the perspective of others, they experience numerous others' irritations, annoyances, and frustrations with various products and services, increasing the likelihood of discovering a problem that the entrepreneur is uniquely equipped to solve and improving the odds of generating a new venture idea that will fulfill that want or need (McMullen, 2010). Similarly, advocates of design thinking suggest that innovation is powered by a thorough understanding, through direct observation, of what people want and need in their lives and what they like or dislike about the way particular products are made, packaged, marketed, sold, and supported (Brown, 2008). Empathy makes sense of these observations by allowing one to imagine the world from multiple perspectives (Brown, 2008). This empathic ability is enabled by social imaginativeness, which facilitates idea generation by allowing the identification of more problems in need of a solution and thus more stimuli to trigger idea generation. Moreover, those high in social imaginativeness generally have a higher concern for others (Davis, 1980), which means other people's problems often translate to their own. This motivates individuals high in social imaginativeness to look for solutions to others' problems, again increasing idea generation. In three different studies using individual difference measures and experimental manipulation, Galinsky and colleagues (2008) found that perspective taking improved idea generation. Similarly, Grant and Berry (2011) found that taking the perspective of others encouraged employees to engage in creative behavior in the field and participants 
to generate more novel and useful ideas in the lab. Formally, we hypothesize:

Hypothesis 2. Social imaginativeness positively relates to new venture idea quantity.

Practical imaginativeness and new venture idea quantity. "Practical imaginativeness" is a cognitive skill to envision something that cannot be or is not currently being observed for the purposes of planning, organizing, analyzing, or managing information, resources, or projects. Because imagination is essential to mental life and consciousness (Hopkins, 2016), Jean-Paul Sartre conceived of it as central to humanity's rational capacity to find significant connections, to draw inferences, and to solve problems (Johnson, 1987). Echoing these sentiments, Shackle (1979: 11) defined imagination as "a mental process by which people choose among thoughts about deeds to be done and moves to be made," and thus considered it fundamental to choice, which, he argued, always involves some degree of uncertainty.

Taking a more structural view of uncertainty, Knight (1921) and Cantillon (1755/1931) suggested that profit is the reward for the entrepreneur who exercises good judgment under uncertainty. But structural uncertainty also requires judgment about an unknown future and is therefore subject to the effects of imagination (McMullen \& Kier, 2016; Tversky \& Kahneman, 1974). We believe practical imaginativeness facilitates the business judgment and willingness to bear uncertainty that is required to shape and develop raw ideas into opportunities (Dimov, 2007a), because it directly supports the process of integrating new with existing knowledge and information (McMullen \& Dimov, 2013) necessary to achieve the multiple insights required for opportunity recognition (Dimov, 2007b).

Practical imaginativeness supports new venture idea quantity by increasing the number of "happy accidents." These happy accidents often begin as solutions generated to solve micro problems on the way to solving some long-term macro problem. For example, Newell and Simon (1972) found that, when facing complex tasks, expert problem-solvers tended to focus on the bottleneck issues, believing that, once those were solved, the rest of the project would be relatively easy to execute. Not only are these bottlenecks often the most technically challenging, requiring expert problem-solving skills, they also have a tendency to reveal solutions with value that transfers beyond their specific context. Individuals gifted at identifying and addressing such trouble spots before they become an issue are often said to exhibit more practical imaginativeness and superior skill in project management because of their prowess in thinking things through (Adamski \& Westrum, 2003). Thus, people with more practical imaginativeness anticipate more problems and generate more solutions for those problems than people with less practical imaginativeness.

Unlike creative imaginativeness and social imaginativeness, the efficacy of practical imaginativeness in generating new venture ideas may be highly contingent on whether one is engaged in solving some overarching problem. For this reason, it is not uncommon to associate this form of entrepreneurial imaginativeness with the engineering type (Stinchfield, Nelson, \& Wood, 2013), or the engineer-tinkerer, entrepreneurial profile exhibited by the founders of Hewlett-Packard (Collins, 2001), as opposed to the social imaginativeness of Apple's design-obsessed pitchman (Isaacson, 2011) or the creative imaginativeness of Tesla's Elon Musk (Vance, 2015). Formally, we hypothesize:

Hypothesis 3. Practical imaginativeness positively relates to new venture idea quantity.

\section{Imaginativeness and New Venture Idea Quality}

Once entrepreneurs generate various new venture ideas, they must evaluate the quality of their existing ideas, and then ultimately select or converge on one idea to further pursue. Prior research that examines highly innovative/creative ideas has viewed "idea quality" in a variety of ways. For example, in a study of research and development scientists and engineers, ideation performance (i.e., idea quality) was viewed as the "ability to develop new, useful innovative ideas" (Salter, Wal, Criscuolo, \& Alexy, 2015: 488). In two experimental studies of new product design, researchers evaluated idea quality based on usefulness, originality, and customer appeal (Dahl et al., 1999, 2001). Magnusson, Wästlund, and Netz (2014) assessed new ideas based on originality, user value, and producibility, while Poetz and Schreier (2012) assessed idea quality based on novelty of the idea, customer benefit, and feasibility. Finally, in Zhao, Hoeffler, and Dahl (2012), new product ideas were evaluated on perceptions of innovativeness, novelty, and originality, while Gielnik and colleagues (2012) rated idea quality based solely on the originality of the idea.

Although these studies and many others use different labels for idea quality, historically, studies that investigate various forms of creative performance are generally simplified into viewing idea quality as 
a function of novelty and usefulness. This view is consistent with Dean, Hender, Rodgers, and Santanen's (2006) review of 90 articles on creativity and idea generation, as well as Plucker, Beghetto, and Dow's (2004) review of 90 different articles from business, education, psychology, and creativity. Plucker and colleagues (2004) concluded that the combination of novelty and usefulness were the most prevalent facets of both explicit and implied definitions of creativity and that scholarship on the assessment of creative products implicitly includes the elements of novelty and usefulness. Thus, we view idea quality as ideas possessing novelty and usefulness.

The mediating role of idea quantity. The purpose of generating a large quantity of ideas is to maximize the likelihood of arriving at the highest quality idea. Osborn's (1963) classic work on brainstorming popularized this notion by outlining specific principles to generate creative ideas, such as "quantity breeds quality" (228). Based on Osborn's work, early idea generation research used quantity as a measure of quality, assuming that, if a sufficient number of ideas were produced, the resulting idea pool would be more likely to contain high-quality ideas (Dean et al., 2006). Along similar lines, De Bono (1992) promoted lateral thinking as a form of brainstorming to generate many new ideas to arrive at the best possible idea. Empirical work supports these views on brainstorming, finding idea quantity to be positively correlated with idea quality (Diehl \& Stroebe, 1987; Gallupe, Dennis, Cooper, Valacich, Bastianutti, \& Nunamaker, 1992; Meadow, Parnes, \& Reese, 1959; Parnes \& Meadow, 1959). Furthermore, Parnes (1967) demonstrated that the highest-quality ideas tended to be within the last half of ideas generated. Similarly, Maier and Hoffman (1964) found that ideas generated later tended to be of superior quality to ideas generated earlier. Assuming that idea quantity is positively related to idea quality, we therefore expect that the more response alternatives an individual can generate, the more likely he or she is to arrive at the potentially best ideas for a solution (D’Zurilla \& Goldfried, 1971).

Not only do we expect that idea quantity will be positively related to idea quality, but also that idea quantity will serve as a mediator between each form of imaginativeness and idea quality. To illustrate, in two of the rare studies that investigated the role of imagination in entrepreneurship (Dahl et al., 1999, 2001), researchers experimentally manipulated imagination visualization versus memory visualization to measure the impact on originality, usefulness, and appeal of new product design. Designers were asked to form a visual image from memory of past experience versus forming a visual image of potential new designs. Results show that designs were rated as more original for those designers who used imagination visualization over memory visualization (Dahl et al., 1999, 2001). We contend that it is creative imaginativeness that supports diverse connections that result in more original designs and in turn higher overall idea quality. This is consistent with previous experimental work performed by Adeyemo (1990), which found that using imagination imagery resulted in more original solutions in creative problem-solving exercises. Results from Dahl and colleagues' (1999) and (2001) studies also showed that, when designers were instructed to imagine the customer using and interacting with the proposed design, the end designs were rated as more useful than when designers received no such instruction. Specifically, those in the customer condition were instructed to see in their mind (Dahl et al., 1999) or try to picture in their mind (Dahl et al., 2001) the subject interacting with the proposed product design. These manipulations, we contend, directly tapped into the designer's social imaginativeness, which resulted in more useful designs and in turn higher overall idea quality. Ultimately, higher-quality ideas stem from creative and social imaginativeness that improve the originality and feasibility of ideas, which operate through the generation of alternatives. Consistent with the principles outlined above regarding brainstorming and idea quantity, the more alternatives one can generate, the greater likelihood of generating an idea that is both original and feasible and thus high quality. Accordingly, we hypothesize:

Hypothesis 4a. Idea quantity will fully mediate the relationship between creative imaginativeness and idea quality.

Hypothesis 4b. Idea quantity will fully mediate the relationship between social imaginativeness and idea quality.

While we expect creative and social imaginativeness to affect idea quality solely through idea quantity, we expect practical imaginativeness to have a more direct effect on idea quality. Practical imaginativeness supports the feasibility of new venture idea quality by facilitating logic and causal inference. To illustrate, in a study of entrepreneurs evaluating a series of opportunities, Haynie et al. (2009) found that entrepreneurs logically assess 
existing resource endowments as well as potential future resources that could be marshalled to exploit the opportunity. They "construct future-oriented cognitive representations of what will be" (Haynie et al., 2009: 338). Anticipating or forecasting "what will be" requires practical imaginativeness. Finding similar results among entrepreneurs engaged in the evaluation of opportunities, Wood and Williams (2014) suggested that entrepreneurs consistently use rules about novelty, resource efficiency, and worst-case scenarios to evaluate opportunities systematically. They use a structured approach called "rule-based thinking" to organize and analyze information that is developed over time from education, experience, and interaction with others (Chaiken \& Trope, 1999; Smolensky, 1988). Rule based thinking allows one to use laws of logic and causal inference to judge the situation and determine an appropriate response (Chaiken, 1980; Devine, 1989; Gilbert, 1991). Similarly, Kant suggested that imagination generates much of the connecting structure by which we have coherent, significant experience, cognition, and language; that it provides unified representations that prevent our experiences from seeming random and chaotic; and that it makes it possible for us to conceptualize what we receive through perception (Johnson, 1987). Thus, practical imaginativeness appears to facilitate logic and causal inference. Furthermore, because idea convergence and selection conjures up notions of applicability, usefulness, and feasibility (Cropley, 2006), and practical imaginativeness is most associated with the logic and reason used to assess applicability, usefulness, and feasibility, we expect that practical imaginativeness will more directly facilitate new venture idea quality. Thus:

Hypothesis 5. Idea quantity will partially mediate the relationship between practical imaginativeness and idea quality.

\section{METHOD}

\section{Sample and Procedures}

This study had a stratified sample of 506 individuals who were from the general working population, were randomly distributed across the United States, and who varied in their entrepreneurial experience. We used an online survey panel, Qualtrics, to help identify our sample. Qualtrics is an online survey software and market research company that provides both broad and targeted participant panels.
Prior studies have utilized Qualtrics as a reliable means of gathering data (e.g., Courtright, Gardner, Smith, McCormick, \& Colbert, 2016; DeCelles, DeRue, Margolis, \& Ceranic, 2012; Long, Bendersky, \& Morrill, 2011). The service sent requests to 700 individuals to take part in our study in exchange for approximately $\$ 5$ in compensation. We received 506 completed responses, representing a response rate of $72.23 \%$. Participants ranged in age from 19 to 88 years old (average $=45.56$ years, $S D=14.52$ ), $53.20 \%$ of the participants were male, $78.46 \%$ were Caucasian, and $62.65 \%$ had a college degree. They possessed over 20 years of work experience (average $=22.45$ years, $S D=13.62$ ) in 20 different industry classifications. In terms of startup experience, 154 participants (30.43\%) had attempted one startup in their career, while 75 (14.82\%) had attempted two, and $43(8.50 \%)$ had attempted three or more.

Identifying entrepreneurs and asking them to report on their previous new venture ideas presents various methodological challenges, such as retrospective bias (Aaker, Kumar, \& Day, 2008; Feldman \& March, 1981; Goodwin, 2009), attribution bias (Fiske \& Taylor, 1991), and self-reporting bias (Sandberg \& Hofer, 1987). In response to these threats, entrepreneurship scholars have advocated for more experimental work (McMullen, Wood, \& Kier, 2016; Shepherd, 2011; Shepherd, Williams, \& Patzelt, 2015). We answered this call by employing a quasiexperimental approach similar to Corbett (2007), Grégoire and Shepherd (2012), and Mueller and Shepherd (2016) in which participants generated new venture ideas based on a common technology and then completed survey measures of our variables. $^{1}$

Specifically, in Part I of the study, participants were invited to take part in a research study on business idea generation. Participants were told that "there are no right or wrong answers to any of the questions ... we are looking to learn about you, so please answer honestly." In addition, all participants had random number identifiers to ensure confidentiality and anonymity. Each participant was then asked to generate as many new venture ideas as possible based upon a description and diagram of facial recognition technology. A description of the scenario instructions and technology narrative are

\footnotetext{
${ }^{1}$ We counterbalanced the order of the predictor and criterion variables to "control for priming effects, itemcontext-induced mood states, and other biases (Podsakoff, MacKenzie, Lee, \& Podsakoff, 2003: 888).
} 
presented in Appendix A. After the participants generated as many new venture ideas as possible, they were asked, in Part II of the study, to select their best idea and then write a short description of that idea. Two expert raters independently scored the quantity (number) of ideas generated in Part I of the study as well as the quality of their selected idea in Part II of the study, which served as the dependent variables.

Consistent with prior research that has utilized raters to evaluate idea quality, we viewed idea quality as the combination of originality and feasibility (Dahl et al., 2001; Gielnik et al., 2012; Poetz \& Schreier, 2012). We operationalized "originality" using Dean and colleagues' (2006) four-point originality scale, which was employed by Gielnik and colleagues (2012) on their study of creativity in the opportunity identification process. The scale ranges from 1 (common, mundane, or boring business idea) to 4 (rare, unusual, ingenious, imaginative, or surprising business idea). Consistent with Poetz and Schreier (2012), we operationalized "feasibility" using a three-point scale, ranging from 1 (low feasibility) to 3 (high feasibility). The overall interrater reliability of the idea quality measure was acceptable $(\mathrm{ICC}=0.92)$ and consistent with other studies using raters to evaluate new venture ideas (Corbett, 2007; Dahl et al., 1999; Grégoire, Barr, \& Shepherd, 2010; Mueller \& Shepherd, 2016).

\section{Measures}

To develop a measure of creative, social, and practical imaginativeness, we followed best practice recommendations by Hinkin (1998) and MacKenzie, Podsakoff, and Podsakoff (2011). First, we reviewed existing literature on problem-solving, creativity, fantasy, perspective taking, empathy, theory of mind, and imagination (e.g., Amabile, 1983; Davis, 1966; Davis, 1980; Dietvorst, Verbeke, Bagozzi, Yoon, Smits, \& van der Lugt, 2009; Gough, 1979; Heppner \& Petersen, 1982; Kirton, 1976; Paal \& Bereczkei, 2007; Spiro \& Weitz, 1990; Tellegen \& Atkinson, 1974; Zhou \& George, 2001) to aid in the generation of items for creative, social, and practical imaginativeness. Second, we conducted in-depth, semi-structured interviews with 16 entrepreneurs to incorporate their language into 77 original scale items. Third, we had 21 subject matter experts perform a content validity assessment on the items to ensure they adequately tapped into each form of imaginativeness. The results of this analysis are presented in Table B1 of Appendix B. The resulting
40 items were then administered to a first sample of 210 respondents using a Qualtrics online panel. Participants ranged in age from 20 to 68 (average $=$ 42.42 years, $S D=10.78$ ), $50 \%$ of the participants were male, $69.52 \%$ were Caucasian, and all were college educated. They were employed full time (minimum $=30$ hours per week, average $=43.24$ hours, $S D=7.49$ ) in a broad range of organizations. They possessed over 20 years of work experience (average $=20.45$ years, $S D=11.20$ ) in 20 different industry classifications. We then conducted a confirmatory factor analysis to eliminate any problematic items and create a parsimonious survey measure. The resulting 18-item survey measure, shown in Table B2 of Appendix B, was rated on a seven-point Likert-type scale ranging from 1 (strongly disagree) to 7 (strongly agree). Our final three-factor measurement model showed acceptable goodness of fit: comparative fit index $(\mathrm{CFI})=0.91$; standardized root mean square residual $($ SRMR $)=$ 0.05; root mean square error of approximation $($ RMSEA $)=0.09$. We compared our three-factor model with an alternative one-factor model, twofactor model, and four-factor model, as shown in Table B3 of Appendix B, which favors the threefactor model. We then administered our survey measure to a new sample of 506 participants. The measure demonstrated strong convergent validity, evidenced by the average variance extracted measure, shown in Table B4 of Appendix B, for each form of imaginativeness being above Fornell and Larcker's (1981) suggested cutoff of 0.50. Additionally, the measure demonstrated strong discriminant validity, as the average variances extracted for each construct were greater than the square of the correlations between comparison constructs in all but one case. Finally, the measure possessed strong reliability of $0.93,0.92$, and 0.89 for creative, social, and practical imaginativeness, respectively.

Consistent with best practice recommendations for control variable usage from Bernerth and Aguinis (2016), we added control variables into our model to rule out alternative explanations of the results and to demonstrate that imaginativeness can explain variance over and above existing variables of creative problem-solving. Previous studies have advocated that experience (Becker, 1964; Cooper, 1981; Westhead, 1995), age (Cressy \& Storey, 1995), and education (Davidsson \& Honig, 2003) are important aspects of general human capital, which is a consistent contributor to the entrepreneurship process (Davidsson \& Honig, 2003; Shane, 2000; Shepherd \& DeTienne, 2005; Unger, Rauch, Frese, \& Rosenbusch, 
2011; Wiklund \& Shepherd, 2008). Additionally, specific human capital in the form of technology familiarity can also influence the identification of entrepreneurial opportunities (Corbett, 2007). Therefore, we controlled for two different forms of knowledge. Knowledge: Education was measured on a seven-point scale of highest educational degree achieved anchored by less than high school, high school/GED, some college but no degree, two-year college degree, four-year college degree, master's degree, doctoral or professional degree (PhD/JD/ MD). Knowledge: Technology Familiarity was the extent of familiarity each participant had with the technology on a seven-point Likert-type scale anchored by 1 (very unfamiliar) to 7 (very familiar). We controlled for two different forms of experience. Experience: Age was measured by the participant's age in years. Experience: Startup was a continuous variable of the number of business startups attempted in one's lifetime. We also controlled for Effort using two different measures. Effort 1 was the amount of time the participant spent completing the survey, measured in seconds, while Effort 2 was the amount of words written when describing ideas. Finally, we controlled for Gender effects, coded 0 for male and 1 for female.

\section{RESULTS}

Descriptive statistics and Pearson correlations between all variables are displayed in Table 2. We used hierarchical linear regression to test the hypothesized model. Examination of linearity, normality, and homoscedasticity based on residual scatterplots revealed no major violations of regression assumptions. Additionally, all variance inflation factor scores were under three, indicating no issues with multicollinearity. We followed statistical procedure recommendations from Aiken and West (1991) and Cohen and Cohen (1983) to interpret the regression effects. Because we hypothesized a mediated model, we employed Baron and Kenny's (1986) approach for testing mediation. First, we established an overall effect of the independent variables (creative, social, and practical imaginativeness) on the dependent variable (idea quality). Second, we established a direct effect of the independent variables on the mediator (idea quantity). Third, we established a relationship between the mediator and dependent variable. Finally, we modeled the dependent variable with the independent variables and mediator included as predictors. If the mediator is significantly correlated with the dependent variable and its inclusion in the model eliminates the significant correlation of the independent variables, then full mediation is present. Alternatively, if inclusion of the mediator reduces but does not eliminate the significant correlation of the independent variables, then partial mediation is present.

As shown in Models 1 to 3 of Table 3, we found that creative imaginativeness $(b=0.06, p<.001)$, social imaginativeness $(b=0.06, p<.001)$, and practical imaginativeness $(b=0.05, p<.001)$ were positively and significantly related to idea quantity over and above knowledge, experience, and motivation. Thus, we find support for Hypotheses 1 to 3. These findings suggest that people high in creative, social, and practical imaginativeness generate a larger set of new venture ideas, presumably due to their ability to make novel connections between seemingly unrelated things (creative imaginativeness), their ability to translate the thoughts, feelings, and intentions of others (social imaginativeness) into new venture ideas, and their ability to identify problems in need of solutions, which in turn triggers a generation of ideas in response to these problems (practical imaginativeness).

In Hypothesis 4a, we predicted that idea quantity would fully mediate the relationship between creative imaginativeness and idea quality. Accordingly, we followed Baron and Kenny's (1986) mediation procedure. As seen in Table 3 (Model 5), creative imaginativeness $(b=0.01, p<.01)$ is positively and significantly related to idea quality. In Model 8, creative imaginativeness $(b=0.01, n s)$ is no longer related to idea quality when the mediator of idea quantity $(b=0.07, p<.001)$ is included in the model. Thus, inclusion of idea quantity as a mediator eliminates the significant correlation between creative imaginativeness and idea quality. Therefore, we find support for Hypothesis 4a that idea quantity fully mediates the relationship between creative imaginativeness and idea quality. We found no such relationship between social imaginativeness and idea quality (Models 6 and 9), and hence find no support for Hypotheses 4b. Finally, in Hypothesis 5, we predicted that idea quantity would partially mediate the relationship between practical imaginativeness and idea quality. As seen in Table 3 (Model 7), practical imaginativeness $(b=0.03, p<.001)$ is positively and significantly related to idea quality. In Model 10, practical imaginativeness $(b=0.02, p<$ $.001)$ is still positively and significantly related to idea quality when the mediator of idea quantity $(b=$ $0.07, p<.001)$ is included in the model. Thus, inclusion of idea quantity as a mediator reduces but 


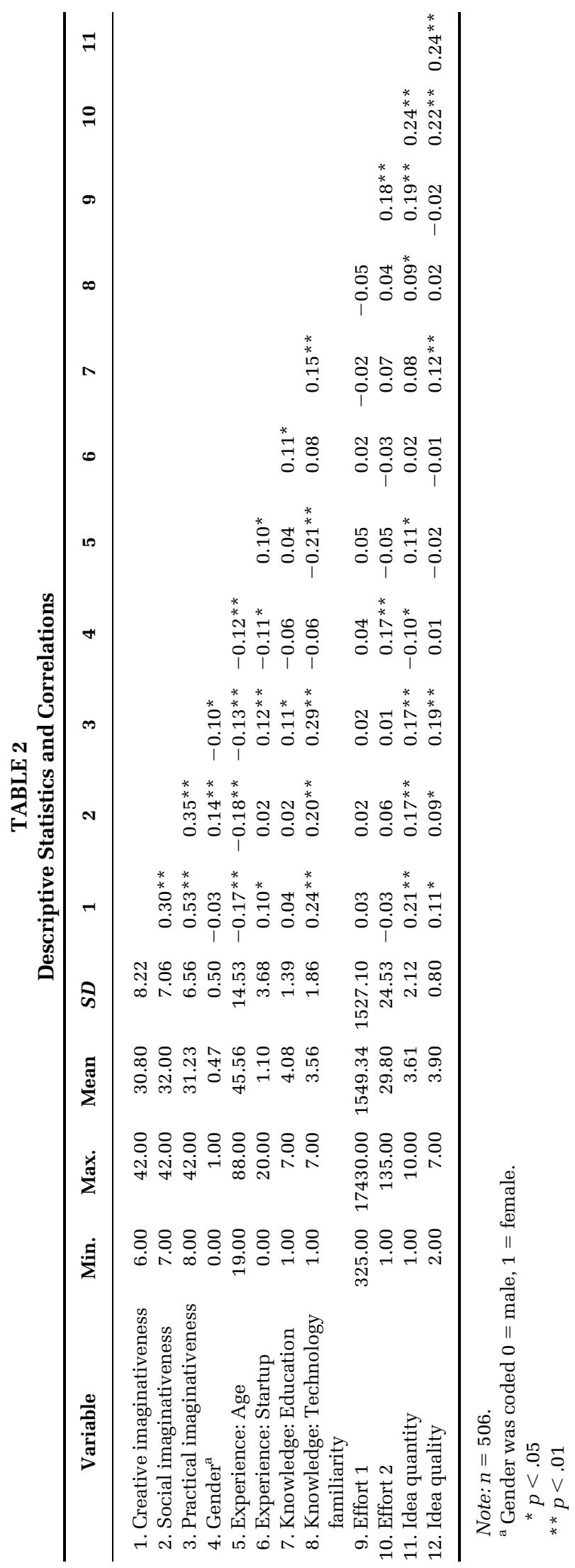




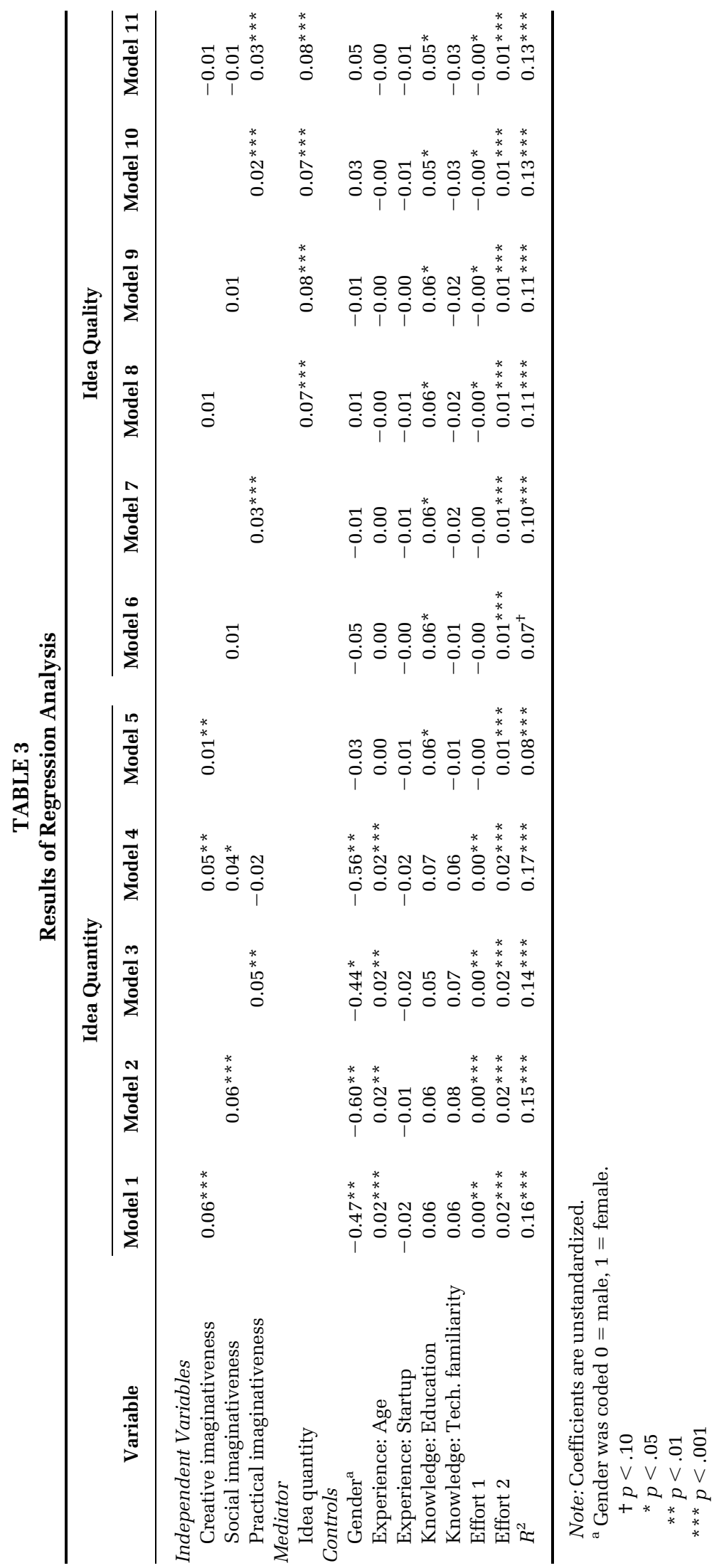


does not eliminate the significant correlation between practical imaginativeness and idea quality. A Sobel test revealed that this reduction was statistically significant $(z=2.62, p<.01)$. Therefore, we find support for Hypothesis 5 that idea quantity partially mediates the relationship between practical imaginativeness and idea quality. These findings suggest that people high in practical imaginativeness converge on their best new venture idea, presumably due to the logic and reason that supports evaluation and selection of ideas.

The $\beta$ coefficient effect sizes on idea quantity and quality are small (e.g., a one unit increase in creative imaginativeness results in 0.06 ideas generated), but these effects are over and above knowledge, experience, and motivation-three variables regularly recognized as significant influencers of human behavior. Moreover, the correlations between creative, social, and practical imaginativeness and idea quantity and quality found in Table 2 are consistent with correlations found between personality traits and leadership behaviors (e.g., Bono \& Judge, 2004), job satisfaction (e.g., Judge, Heller, \& Mount, 2002), and business creation (e.g., Rauch \& Frese, 2007), for example. Furthermore, the combined explained variance attributed to creative, social, and practical imaginativeness may not appear large at first (approximately $5 \%$ on idea quantity and $2 \%$ on idea quality, explained in the supplemental analysis section below), but entrepreneurial imaginativeness is a skill likely to be employed repeatedly throughout the entrepreneurship process, creating cumulative effects. Simulations by Martell, Lane, and Emrich (1996), for example, demonstrated that even the smallest effects (e.g., effect size of $1 \%$ explained variance) can have powerful consequences when the effect is repeated over time. Thus, because there are likely to be multiple opportunities to exercise entrepreneurial imaginativeness in the generation, selection, and development of new venture ideas, small effects in idea quantity and quality can have compounded effects with large implications.

\section{Supplemental Analysis: Examination of Relative Weights}

To supplement our regression analysis, we performed a relative weight analysis on our data, as it allows for a greater understanding of the impact of particular predictors relative to others in a regression model, aids in theory building, and can increase the determination of practical utility (Tonidandel \& LeBreton, 2011). Therefore, to better understand the relative strength of the three forms of imaginativeness in explaining the quantity and quality of new venture ideas, we used relative weight analysis (Johnson, 2000; Tonidandel \& LeBreton, 2015; Tonidandel, LeBreton, \& Johnson, 2009). Although multicollinearity is unlikely to be an issue in these data, as evidenced by all variance inflation factor scores below three, the three forms of imaginativeness are moderately correlated. Thus, relative weight analysis is an appropriate supplemental technique because the partitioning of variance among multiple correlated predictors is difficult (Darlington, 1968). Relative weight analysis "addresses the problem caused by correlated predictors by using a variable transformation approach to create a set of new predictors that are maximally related to the original predictors but are orthogonal to one another ... which means the coefficients no longer suffer from the problems associated with collinearity" (Tonidandel \& LeBreton, 2015: 208). The results of this analysis are presented in Table 4. Consistent with Tonidandel and colleagues (2009), the 95\% confidence intervals for the relative weights (Johnson, 2004) and significance tests were based on a bootstrapping approach with 10,000 replications. Results indicate that creative, social, and practical imaginativeness each explain a statistically significant amount of variance in the quantity of ideas, as none of the $95 \%$ confidence intervals for the tests of significance contained zero. Creative imaginativeness ( $\mathrm{RW}=0.03, p<.05$ ), social imaginativeness ( $\mathrm{RW}=0.02, p<.05$ ), and practical imaginativeness $(\mathrm{RW}=0.01, p<.05)$ were significantly related to new venture idea quantity. Additionally, practical imaginativeness (RW $=0.01, p<$ .05) was significantly related to new venture idea quality.

\section{DISCUSSION}

Although researchers have made great strides in understanding opportunity discovery, evaluation, and exploitation (Shane \& Venkataraman, 2000), extant literature has fallen short theoretically, methodologically, and empirically in understanding the precursor of these opportunities: new venture ideas (Davidsson, 2015; Shane, 2012). By studying idea quantity and quality, we sought to gain a better understanding of the critical starting point for entrepreneurship, innovation, and strategic change, and, by taking a cognitive perspective (Baron, 2004; Grégoire, Corbett, \& McMullen, 2011; Mitchell et al., 2007), we sought to unpack whether, how, and why entrepreneurial imaginativeness is fundamental to 
TABLE 4

Results of Relative Weight Analysis

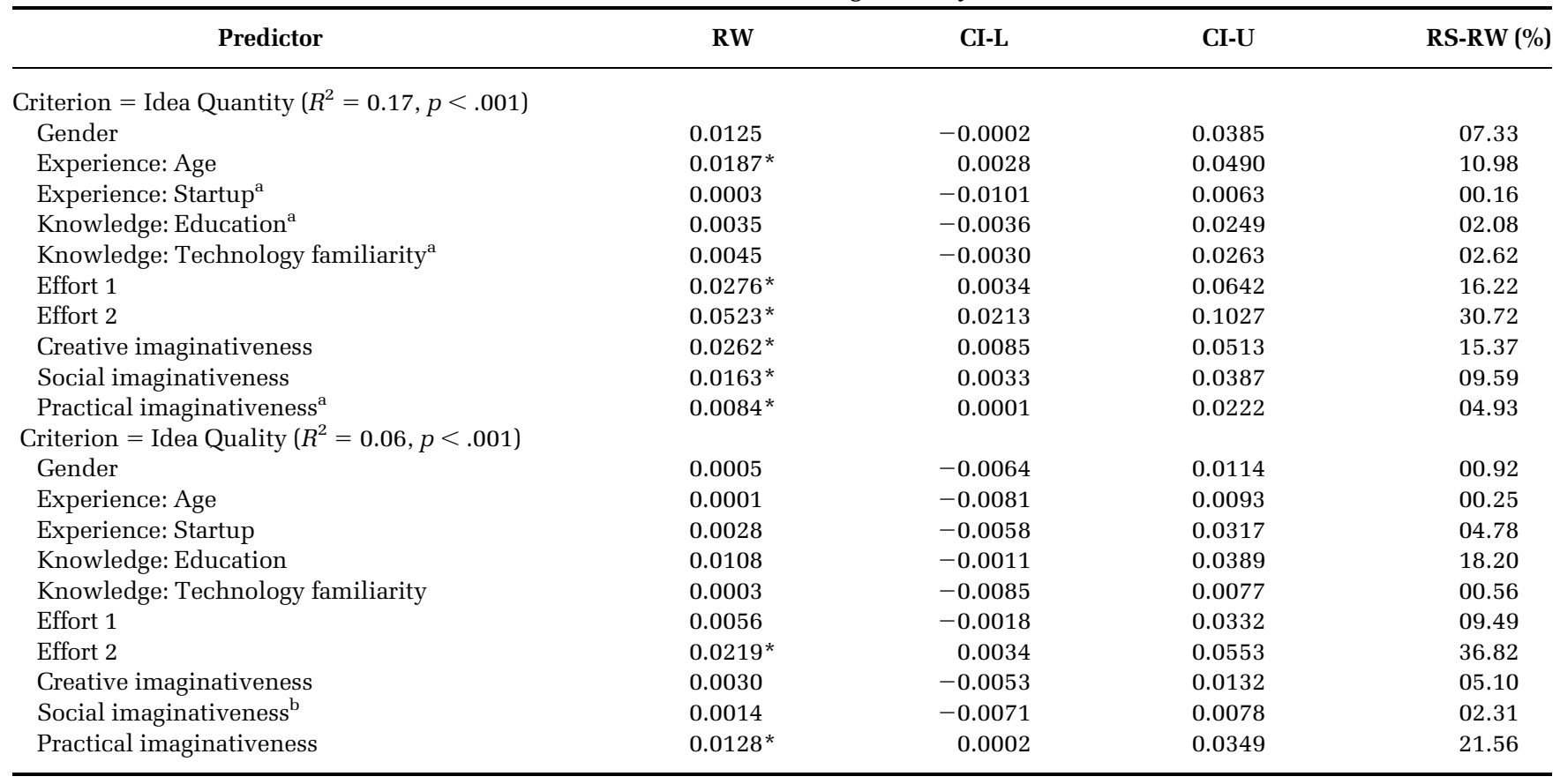

Note:RW = raw relative weight (within rounding error raw weights will sum to $R^{2}$ ), CI-L = lower bound of confidence interval used to test the statistical significance of raw weight, CI-U = upper bound of confidence internal used to test the statistical significance of raw weight, RS-RW = relative weight rescaled as a percentage of predicted variance in the criterion variable attributable to each predictor (within rounding error rescaled weights sum to $100 \%$ ).

${ }^{a}$ The raw relative weight for this variable differs significantly from the raw relative weight obtained for Creative imaginativeness.

$\mathrm{b}$ The raw relative weight for this variable differs significantly from the raw relative weight obtained for Practical imaginativeness.

${ }^{*} p<.05$

new venture ideation. In the process, we believe our efforts contribute to theory development and empirical advancement in entrepreneurship and creative problem-solving.

We drew from literature in creativity (Runco, 2004), empathy (Davis, 1980), theory of mind (Bagozzi et al., 2013), and problem-solving (D'Zurilla \& Goldfried, 1971) to clarify the ontological nature of creative, social, and practical imaginativeness as well as how and why each is integral to new venture idea quantity and quality. We found that, over and above the effects of knowledge, experience, and motivation, creative, social, and practical imaginativeness each predict higher levels of new venture idea quantity. Creative imaginativeness allows individuals to make connections between seemingly unrelated pieces of information to form new means-ends relationships that result in the generation of new venture ideas. Social imaginativeness allows individuals to understand the needs of others, which increases the identification of more problems in need of a solution, and thus more stimuli to trigger idea quantity. Practical imaginativeness allows individuals to identify problems in need of solutions, prompting a perceived need to generate ideas, and generation of ideas in response to the salience of this need. In turn, we found that idea quantity fully mediates the relationship between creative imaginativeness and idea quality, which is consistent with prior work on brainstorming that has shown that divergent thinking directly relates to idea quantity, which in turn increases the likelihood of idea quality (Diehl \& Stroebe, 1987; Gallupe et al., 1992; Meadow et al., 1959; Parnes \& Meadow, 1959). We also found that idea quantity partially mediates the relationship between practical imaginativeness and idea quality. This is presumably due to practical imaginativeness' natural tendency to edit or screen ideas for feasibility yielding a more direct effect on idea quality. Consequently, by explaining why creative, social, and practical imaginativeness facilitate new venture idea quantity and quality, we responded to the call by Shepherd (2015: 493) to do more work in "understanding the 'why' underlying the activities of 
organizational emergence" and offer insight into "the micro-foundations of entrepreneurial action."

\section{Theoretical Implications}

The results of our research offer insights into the micro-foundations of entrepreneurial action by informing existing opportunity recognition research. For example, entrepreneurship scholars have employed various tools to explain opportunity recognition. Explanations have included pattern recognition (Baron \& Ensley, 2006), structural alignment (Grégoire et al., 2010), analogical/metaphorical reasoning (Cornelissen \& Clarke, 2010), perspective taking/empathy (McMullen, 2010, 2015), and improvisation (Hmieleski \& Corbett, 2008) to name a few. These explanations share similarities in that each occurs within the individual's mind to recognize opportunities through new or novel patterns (pattern recognition), market and technology alignment (structural alignment), reasoning (analogical/metaphorical reasoning), viewpoints (perspective taking), or spontaneous action (improvisation). Imaginativeness involves the mental simulation used to find patterns, align markets and technology, apply reasoning, foresee different views, and even adlib on what has yet to be created. Hence, entrepreneurial imaginativeness supports and enables opportunity recognition by providing a possible mechanism underlying existing opportunity recognition research.

A similar connection can be made with counterfactual thinking, a common heuristic for opportunity recognition cited in the entrepreneurship literature (e.g., Arora, Haynie, \& Laurence, 2013; Baron, 2000; Gaglio, 2004). "Counterfactual thinking” is mental representations of alternatives to the past (Roese, 1997), or the imagination of alternatives to reality (Gilovich \& Medvec, 1995; Kahneman \& Tversky, 1982; Markman, Gavanski, Sherman, \& McMullen, 1993). Counterfactual thinking is imagining "what might have been" (Baron, 2000), reflecting on outcomes and events that might have occurred had circumstances somehow been different. Consistent with Roese (1997), we view counterfactual thinking as a subset of mental simulation (Roese, 1997), or the imaginative mental construction of scenarios (Kahneman \& Tversky, 1982; Taylor \& Schneider, 1989). Thus, entrepreneurial imaginativeness serves as a potential underlying mechanism of when entrepreneurs reflect on past actions or inactions and then imagine how things could have gone differently, a notion commonplace in opportunity recognition research (Baron, 2000; Gaglio, 2004).
In addition to contributing to opportunity recognition research, our findings suggest that entrepreneurial imaginativeness may have an effect beyond new venture ideas to existing theories of entrepreneurial action. By "entrepreneurial action," we are referring to a "behavior in response to a judgmental decision under uncertainty about a possible opportunity for profit” (McMullen \& Shepherd, 2006: 134). This behavioral response, as explained by McMullen and Shepherd (2006), occurs via a two-stage model of third-person and first-person opportunity. In a "third-person opportunity," opportunities arise from technological change for anyone who has the requisite knowledge and motivation to notice (McMullen \& Shepherd, 2006). However, believing one has recognized a third-person opportunity does not guarantee that one possesses or believes he possesses the knowledge and motivation necessary to exploit it (Shepherd, McMullen, \& Jennings, 2007); action depends on whether the individual is motivated enough to act, given the uncertainty he or she expects to encounter in pursuit of a third-person opportunity (McMullen \& Shepherd, 2006). Sufficient knowledge and motivation are needed to see and seize opportunity. We argue this interaction occurs via imaginativeness, which serves as the catalyst that turns the resource inputs of knowledge and motivation into the new venture ideas that are generated and sometimes selected.

For example, entrepreneurs use their creative imaginativeness to transform their knowledge and motivation into new combinations that result in third-person opportunity beliefs. When assessing "first-person opportunity," entrepreneurs use their practical imaginativeness to look into the future and assess feasibility; do they have the right knowledge and experience to act upon the opportunity? In addition, entrepreneurs use their social imaginativeness to put themselves in the shoes of potential customers or investors to determine whether they can convince others that they have the knowledge and motivation to execute on the opportunity. Therefore, without entrepreneurial imaginativeness, it is difficult-to-impossible to form a third-person opportunity belief, and harder still for it to become a first-person opportunity belief.

Effectuation is another prominent theory of entrepreneurial action that could be informed by our research. In effectuation theory, the entrepreneur takes a set of means as given and focuses on selecting between possible effects that can be created with that set of means (Sarasvathy, 2001). The idea is that an effectual approach is best utilized to uncover and 
exploit opportunities in new markets with high levels of uncertainty (Sarasvathy, 2001). We contend this argument is incomplete, because having more means at their disposal does not necessarily lead to better goals if that individual lacks the ability to imagine how those means might be better employed, regardless of how much he or she may desire a particular end. Thus, prescribing an effectual approach to individuals who lack entrepreneurial imaginativeness or who lack the form of it needed for particular tasks may be bad practice, stemming from incomplete theory or under-identified models. Thus, effectuation theory could be underdeveloped, because it assumes that imaginativeness is ubiquitous and evenly distributed. Our results demonstrate that individuals in fact vary in their amount and forms of imaginativeness. Thus, differences exist regarding how entrepreneurs transform means or resources into products via effectuation. Higher levels of creative imaginativeness allow entrepreneurs to generate more novel ways to employ their resources, for instance. Furthermore, because effectuation is predicated on interacting with others and engaging with stakeholders (McMullen, 2015; Sarasvathy \& Dew, 2005), entrepreneurs must use their social imaginativeness to "discover new means and establish new goals that allow for revaluation of means and possible courses of action" (Fisher, 2012: 1026).

Our research on entrepreneurial imaginativeness may also inform bricolage, or "making do by applying combinations of resources at hand to new problems and opportunities" (Baker \& Nelson, 2005: 33). Bricoleurs have an identity of "making it work" using any means or timeframe necessary (Stinchfield et al., 2013). "Any means" often translates to using resources in ways for which they were not originally designed (Baker \& Nelson, 2005). Bricoleurs engage in "resource repackaging, transposing, and recombining (Rice \& Rogers, 1980) to solve problems and uncover opportunities" (Fisher, 2012: 1026). It is creative imaginativeness that allows for this repackaging and recombining of resources to make something ostensibly out of nothing. Not only do bricoleurs use their creative imaginativeness to overcome resource constraints (Fisher, 2012), they also use their practical imaginativeness to spot bottlenecks and apply existing methods to solve new problems. In addition, bricoleurs have a "keen sense of both their market niche and what their customers would permit" (Stinchfield et al., 2013: 905). This understanding of their market and customer base comes from using their social imaginativeness to understand the thoughts, feelings, and intentions of others. They actively involve customers and suppliers in their process using social imaginativeness along the way to reach an agreeable solution by all.

Entrepreneurial imaginativeness may also serve to enable narrative/storytelling (Lounsbury \& Glynn, 2001) and inductive analogical/metaphorical reasoning (Cornelissen \& Clarke, 2010). Entrepreneurial narratives allow actors to look back into the past to make sense of what transpired (Weick, 1995). According to Schutz (1967), people make sense of information by looking back upon past events and engaging in retrospective analysis. Weick (1995) called this process "sensemaking." The implication is that events and actions from the past are inevitably vulnerable to interpretation and reinterpretation in the present (Gioia, Corley, \& Fabbri, 2002). Thus, "history is malleable because events, actions, and attributes from the past are all susceptible to reinterpretation" (Gioia et al., 2002: 629). How does this reinterpretation work? Creative imaginativeness fills in the gaps of our memory by making new connections that help make sense of our past experiences. For example, when we tell stories, we often do not remember all of the details, so our imagination fills in the holes to help make sense of what occurred. In fact, entrepreneurs do this all the time, using analogies or metaphors in their speech to imagine future opportunities and make those opportunities understood by others (Cornelissen \& Clarke, 2010; Hill \& Levenhagen, 1995). Because these stories, analogies, and metaphors are intended to influence others, they also involve a process of sensegiving (Gioia \& Chittipeddi, 1991), which is likely to be fueled by social imaginativeness.

\section{Avenues for Future Research}

Staged models of entrepreneurial action (McMullen \& Shepherd, 2006), effectuation theory (Sarasvathy, 2001), bricolage (Baker \& Nelson, 2005), and analogical/metaphorical reasoning (Cornelissen \& Clarke, 2010) are by no means alone in their possible dependence on imaginativeness. They are joined by a host of models from academe and practice that require imagination to function. These include improvisation (Hmieleski \& Corbett, 2008), design thinking (Brown, 2008), and the lean startup (Ries, 2011). Is the efficacy of these models contingent on the entrepreneurial imaginativeness of the individuals who implement them? By laying some of the theoretical foundation and developing some of the methodological tools needed, we hope we have begun to enable researchers to investigate such a question. 
In addition to investigating the role of entrepreneurial imaginativeness in the models described above, future research could greatly expand the generalizability of our findings across different levels of analysis, phases of entrepreneurship, and contexts. For example, teams, not individuals, found the vast majority of new ventures (Cardon, Post, \& Forster, 2017; Chowdhury, 2005; Klotz, Hmieleski, Bradley, \& Busenitz, 2014; Lechler, 2001; West, 2007). Accordingly, future research exploring how entrepreneurial imaginativeness of individuals mix or combine to form team-level entrepreneurial imaginativeness may increase our understanding of new venture ideation. Additionally, research has just begun to ask whether entrepreneurs as a population possess higher levels of imaginativeness and how such imaginativeness might be enhanced (e.g., McMullen \& Kier, 2017). Could it be that successful entrepreneurial action requires higher levels of imaginativeness? If so, does being imaginative necessarily predispose a person toward becoming an entrepreneur, trying entrepreneurship, or succeeding at entrepreneurship, or, vice versa, does engaging in entrepreneurship contribute to developing one's imaginativeness? Future longitudinal research is most likely needed to answer such questions, and to further discriminate among the antecedents, correlates, and consequents of imaginativeness.

There is reason to believe that mindfulness may serve as one of many possible antecedents to imaginativeness. Mindfulness is bringing one's complete attention and awareness to the experiences occurring in the present moment (Brown \& Ryan, 2003), and has begun to attract attention from management scholars because of its positive impact on cognition, emotional regulation, life satisfaction, and general well-being (Good et al., 2016). Mindful individuals refrain from evaluation, self-criticism, or attempts to eliminate or change the phenomena they observe, bringing instead an attitude of friendly curiosity, interest, and acceptance (Baer, Smith, \& Allen, 2004; Segal, Williams, \& Teasdale, 2002). This refrain from evaluation or self-criticism may open up one's mind to the possibilities of what could be. Because mindful individuals are more open to the environment and new information, they are likely to find new ways to structure problems by developing a new perspective (Corbett \& McMullen, 2006). Thus, mindful individuals may have a greater willingness and ability to utilize their imaginativeness to explore novel ideas, products, methods, or even strategies that will allow them to better generate new venture ideas.
Given the importance of imaginativeness to new venture ideation, future research may also benefit by examining whence entrepreneurial imaginativeness comes and whether it can be developed. Research on topics as varied as drawing (Fish \& Scrivener, 1990), writing composition (Berthoff, 1982; Collins, 1991), and autism (Wolfberg, 2009) suggests that, through deliberate practice, cognitive skills that draw heavily on imaginativeness may be developed, even if individuals start with an innate deficit (Valett, 1983). For example, many people do not believe that they can draw and fewer still believe that they have the creative imaginativeness to draw images from their mind's eye, but studies show that the absence of such skill is primarily from a lack of practice, as opposed to some innate and rigid deficiency (Ericsson, 1998). Even in instances of innate disability, such as autism, research suggests that individuals can be taught how to improve their social imaginativeness via cognitive strategies (Wolfberg, 2009).

Furthermore, ideation in the initial business concept is but one phase in the entrepreneurship process. Entrepreneurs must also raise capital, build efficient production, distribute their product or service, and adapt to changing market conditions. It would seem that creative, social, and practical imaginativeness would be important in these other phases of entrepreneurship as novel creation (Ward, 2004), perspective taking/empathy (McMullen, 2010, 2015; Prandelli, Pasquini, \& Verona, 2016), and planning/organizing (Gielnik, Frese, \& Stark, 2015) are foundational to entrepreneurship. Therefore, it seems prudent to measure entrepreneurial imaginativeness in future studies across different phases in the entrepreneurship process. Finally, ideation is just as relevant within existing organizations as it is within new ventures. Organizations need fresh ideas to foster new product development, strategic initiatives, change, or innovation (Covin \& Miles, 1999). Therefore, future research might explore the role of entrepreneurial imaginativeness within work teams from organization behavior (Mathieu, Maynard, Rapp, \& Gilson, 2008), corporate entrepreneurship (Kuratko, Hornsby, \& Hayton, 2015; Morris, Kuratko, \& Covin, 2011), or within top management teams from strategic management (Carpenter, Geletkanycz, \& Sanders, 2004).

Although we believe that our findings have led to theoretical development and empirical advancement in entrepreneurship and creative problem-solving, alternative approaches, worldviews, and conceptualizations of imagination/imaginativeness may promise fruitful avenues as well. In this paper, we have 
employed a mechanistic worldview (Pepper, 1942) and post-positivistic philosophical approach to imagination by explicitly measuring imaginativeness to better understand this critical yet underexplored phenomenon. Instead of examining the cognitive skill of imaginativeness, however, future research may wish to adopt other definitions or philosophical worldviews of imagination (see Kind, 2016) in hopes of examining it more directly. In addition, our study employed a cross-sectional design, which could suffer limitations if entrepreneurship is viewed as a process that unfolds over time (Gupta, Chiles, \& McMullen, 2016; McMullen \& Dimov, 2013). Therefore, future research may benefit by broadening our understanding of the unconscious, embodied, and sensory nature of imagination through the use of interpretive studies (e.g., case studies, ethnographies, and hermeneutic or discourse analyses) (Elias, Chiles, Duncan, \& Vultee, 2018).

\section{CONCLUSION}

Imaginativeness is fundamental to generating and selecting ideas for new ventures. Yet, we have a limited understanding of how these ideas are formed and the role that imaginativeness plays in this process. To help fill this gap, we sought to provide a theoretically grounded conceptualization of what entrepreneurial imaginativeness is and what it does in regard to new venture ideation. Although our research offers but a single step in a long and arduous journey, it is a necessary step and one that we hope inspires others to join us in exploring a topic widely recognized as essential to both the initiation and successful culmination of entrepreneurial action.

\section{REFERENCES}

Aaker, D. A., Kumar, V., \& Day, G. S. 2008. Marketing research (9th ed.). New York, NY: John Wiley \& Sons.

Adamski, A., \& Westrum, R. 2003. Requisite imagination: The fine art of anticipating what might go wrong. In E. Hollnagel (Ed.), Handbook of cognitive task design: 193-220. Boca Raton, FL: CRC Press.

Adeyemo, S. A. 1990. Thinking imagery and problemsolving. Psychological Studies, 35: 179-190.

Aiken, L. S., \& West, S. G. 1991. Multiple regression: Testing and interpreting interactions. Thousand Oaks, CA: SAGE.

Amabile, T. M. 1983. The social psychology of creativity: A componential conceptualization. Journal of Personality and Social Psychology, 45: 357-376.
Amabile, T. M. 1988. A model of creativity and innovation in organizations. Research in Organizational Behavior, 10: 123-167.

Amabile, T. M., Barsade, S. G., Mueller, J. S., \& Staw, B. M. 2005. Affect and creativity at work. Administrative Science Quarterly, 50: 367-403.

Amabile, T. M., Conti, R., Coon, H., Lazenby, J., \& Herron, M. 1996. Assessing the work environment for creativity. Academy of Management Journal, 39: 11541184.

Arieti, S. 1976. Creativity: The magic synthesis. New York, NY: Basic Books.

Arora, P., Haynie, J. M., \& Laurence, G. A. 2013. Counterfactual thinking and entrepreneurial self-efficacy: The moderating role of self-esteem and dispositional affect. Entrepreneurship Theory and Practice, 37: 359-385.

Baer, R. A., Smith, G. T., \& Allen, K. B. 2004. Assessment of mindfulness by self-report: The Kentucky inventory of mindfulness skills. Assessment, 11: 191-206.

Bagozzi, R. P., Verbeke, W. J., Dietvorst, R. C., Belschak, F. D., van den Berg, W. E., \& Rietdijk, W. J. 2013. Theory of mind and empathic explanations of Machiavellianism: A neuroscience perspective. Journal of Management, 39: 1760-1798.

Baker, T., \& Nelson, R. E. 2005. Creating something from nothing: Resource construction through entrepreneurial bricolage. Administrative Science Quarterly, 50: 329-366.

Baron, R. A. 2000. Counterfactual thinking and venture formation: The potential effects of thinking about "what might have been." Journal of Business Venturing, 15: 79-91.

Baron, R. A. 2004. The cognitive perspective: A valuable tool for answering entrepreneurship's basic "why" questions. Journal of Business Venturing, 19: 221-239.

Baron, R. A., \& Ensley, M. D. 2006. Opportunity recognition as the detection of meaningful patterns: Evidence from comparisons of novice and experienced entrepreneurs. Management Science, 52: 1331-1344.

Baron, R. M., \& Kenny, D. A. 1986. The moderatormediator variable distinction in social psychological research: Conceptual, strategic, and statistical considerations. Journal of Personality and Social Psychology, 51: 1173-1182.

Barreto, H. 1989. The entrepreneur in microeconomic theory: Disappearance and explanation. London, U.K.: Routledge.

Basadur, M., Graen, G. B., \& Green, S. G. 1982. Training in creative problem solving: Effects on ideation and problem finding and solving in an industrial research organization. Organizational Behavior and Human Performance, 30: 41-70. 
Basadur, M., Graen, G., \& Wakabayashi, M. 1990. Identifying individual differences in creative problem solving style. The Journal of Creative Behavior, 24: 111-131.

Becker, G. S. 1964. Human capital. Chicago, IL: University of Chicago Press.

Bernerth, J. B., \& Aguinis, H. 2016. A critical review and best-practice recommendations for control variable usage. Personnel Psychology, 69: 229-283.

Berthoff, A. E. 1982. Forming, thinking, writing: The composing imagination. Portsmouth, NH: Heinemann Educational.

Bono, J. E., \& Judge, T. A. 2004. Personality and transformational and transactional leadership: A metaanalysis. The Journal of Applied Psychology, 89: 901-910.

Brophy, D. R. 1998. Understanding, measuring, and enhancing individual creative problem-solving efforts. Creativity Research Journal, 11: 123-150.

Brown, K. W., \& Ryan, R. M. 2003. The benefits of being present: Mindfulness and its role in psychological well-being. Journal of Personality and Social Psychology, 84: 822-848.

Brown, T. 2008. Design thinking. Harvard Business Review, 86: 84-92.

Brown, T. 2009. Change by design. New York, NY: HarperCollins.

Campos, A., \& González, M. A. 1993a. Is imagery vividness a determinant factor in creativity? Bulletin of the Psychonomic Society, 31: 560-562.

Campos, A., \& González, M. A. 1993b. Vividness of imagery and creativity. Perceptual and Motor Skills, 77: 923-928.

Campos, A., \& González, M. A. 1995. Effects of mental imagery on creative perception. Journal of Mental Imagery, 19: 67-75.

Campos, A., \& Perez, M. J. 1989. High and low imagers and their scores on creativity. Perceptual and Motor Skills, 68: 403-406.

Cantillon, R. 1931. Essai sur la nature du commerce en général (H. Higgs, Trans.). London, U.K.: Macmillan. (Original work published 1755)

Cardon, M. S., Post, C., \& Forster, W. R. 2017. Team entrepreneurial passion: Its emergence and influence in new venture teams. Academy of Management Review, 42: 283-305.

Carland, J. W., Hoy, F., Boulton, W. R., \& Carland, J. A. C. 1984. Differentiating entrepreneurs from small business owners: A conceptualization. Academy of Management Review, 9: 354-359.

Carpenter, M. A., Geletkanycz, M. A., \& Sanders, W. G. 2004. Upper echelons research revisited: Antecedents, elements, and consequences of top management team composition. Journal of Management, 30: 749-778.

Casson, M. 1982. The entrepreneur: An economic theory. Totowa, NJ: Barnes \& Noble.

Chaiken, S. 1980. Heuristic versus systematic information processing and the use of source versus message cues in persuasion. Journal of Personality and Social Psychology, 39: 752-766.

Chaiken, S., \& Trope, Y. 1999. Dual process theories in social psychology. New York, NY: Guildford Press.

Chiles, T. H., Bluedorn, A. C., \& Gupta, V. K. 2007. Beyond creative destruction and entrepreneurial discovery: A radical Austrian approach to entrepreneurship. Organization Studies, 28: 467-493.

Chiles, T. H., Tuggle, C. S., McMullen, J. S., Bierman, L., \& Greening, D. W. 2010. Dynamic creation: Extending the radical Austrian approach to entrepreneurship. Organization Studies, 31: 7-46.

Chowdhury, S. 2005. Demographic diversity for building an effective entrepreneurial team: Is it important? Journal of Business Venturing, 20: 727-746.

Cohen, J., \& Cohen, P. 1983. Applied multiple regression/ correlation analyses for the behavioral sciences (2nd ed.). Hillsdale, NJ: Lawrence Erlbaum.

Collins, C. 1991. The poetics of the mind's eye: Literature and the psychology of imagination. Philadelphia, PA: University of Pennsylvania Press.

Collins, J. C. 2001. Good to great: Why some companies make the leap... and others don't. New York, NY: Random House.

Collins English dictionary \& thesaurus (2nd ed.). 2006. Glasgow, U.K.: HarperCollins.

Cooper, A. C. 1981. Strategic management: New ventures and small business. Long Range Planning, 14: 39-45.

Corbett, A. C. 2007. Learning asymmetries and the discovery of entrepreneurial opportunities. Journal of Business Venturing, 22: 97-118.

Corbett, A. C., \& McMullen, J. M. 2006. Perceiving and shaping new venture opportunities through mindful practice. In A. Zacharakis \& S. Spinelli, Jr. (Eds.), Entrepreneurship: The engine of growth: Vol. 2Process: 43-64. Westport, CT: Praeger.

Cornelissen, J. P., \& Clarke, J. S. 2010. Imagining and rationalizing opportunities: Inductive reasoning and the creation and justification of new ventures. Academy of Management Review, 35: 539-557.

Cottrell, L. S., Jr., \& Dymond, R. F. 1949. The empathic responses: A neglected field for research. Psychiatry, 12: 355-359.

Courtright, S. H., Gardner, R. G., Smith, T. A., McCormick, B. W., \& Colbert, A. E. 2016. My family made me do it: 
A cross-domain, self-regulatory perspective on antecedents to abusive supervision. Academy of Management Journal, 59: 1630-1652.

Covin, J. G., \& Miles, M. P. 1999. Corporate entrepreneurship and the pursuit of competitive advantage. Entrepreneurship Theory and Practice, 23: 47-63.

Cressy, R., \& Storey, D. 1995. New firms and their bank. London, U.K.: National Westminster Bank.

Cropley, A. 2006. In praise of convergent thinking. Creativity Research Journal, 18: 391-404.

D’Zurilla, T. J., \& Goldfried, M. R. 1971. Problem solving and behavior modification. Journal of Abnormal Psychology, 78: 107-126.

Dahl, D. W., Chattopadhyay, A., \& Gorn, G. J. 1999. The use of visual mental imagery in new product design. JMR, Journal of Marketing Research, 36: 18-28.

Dahl, D. W., Chattopadhyay, A., \& Gorn, G. J. 2001. The importance of visualization in concept design. Design Studies, 22: 5-26.

Darlington, R. B. 1968. Multiple regression in psychological research and practice. Psychological Bulletin, 69: 161-182.

Davidsson, P. 2003. The domain of entrepreneurship research: Some suggestions. Advances in Entrepreneurship, Firm Emergence, and Growth, 6: 315372.

Davidsson, P. 2015. Entrepreneurial opportunities and the entrepreneurship nexus: A re-conceptualization. Journal of Business Venturing, 30: 674-695.

Davidsson, P., \& Honig, B. 2003. The role of social and human capital among nascent entrepreneurs. Journal of Business Venturing, 18: 301-331.

Davis, G. A. 1966. Current status of research and theory in human problem solving. Psychological Bulletin, 66: 36-54.

Davis, M. H. 1980. A multidimensional approach to individual differences in empathy. Washington, DC: American Psychological Association.

Davis, M. H. 1983. Measuring individual differences in empathy: Evidence for a multidimensional approach. Journal of Personality and Social Psychology, 44: 113-126.

Dean, D. L., Hender, J. M., Rodgers, T. L., \& Santanen, E. L. 2006. Identifying quality, novel, and creative ideas: Constructs and scales for idea evaluation. Journal of the Association for Information Systems, 7: 646-699.

De Bono, E. 1992. Serious creativity: Using the power of lateral thinking to create new ideas. New York, NY: HarperCollins.

DeCelles, K. A., DeRue, D. S., Margolis, J. D., \& Ceranic, T. L. 2012. Does power corrupt or enable? When and why power facilitates self-interested behavior. The Journal of Applied Psychology, 97: 681-689.

Devine, P. G. 1989. Stereotypes and prejudice: Their automatic and controlled components. Journal of Personality and Social Psychology, 56: 5-18.

Diehl, M., \& Stroebe, W. 1987. Productivity loss in brainstorming groups: Toward the solution of a riddle. Journal of Personality and Social Psychology, 53: 497-509.

Dietvorst, R. C., Verbeke, W. J., Bagozzi, R. P., Yoon, C., Smits, M., \& van der Lugt, A. 2009. A sales forcespecific theory-of-mind scale: Tests of its validity by classical methods and functional magnetic resonance imaging. JMR, Journal of Marketing Research, 46: 653-668.

Dimov, D. 2007a. Beyond the single-person, single-insight attribution in understanding entrepreneurial opportunities. Entrepreneurship Theory and Practice, 31: 713-731.

Dimov, D. 2007b. From opportunity insight to opportunity intention: The importance of person-situation learning match. Entrepreneurship Theory and Practice, 31: 561-583.

Dimov, D. 2011. Grappling with the unbearable elusiveness of entrepreneurial opportunities. Entrepreneurship Theory and Practice, 35: 57-81.

Eckhardt, J. T., \& Shane, S. A. 2003. Opportunities and entrepreneurship. Journal of Management, 29: 333349.

Elias, S. R. S. T. A., Chiles, T. H., Duncan, C. M., \& Vultee, D. M. 2018. The aesthetics of entrepreneurship: How arts entrepreneurs and their customers cocreate aesthetic value. Organization Studies, 39: 345-372.

Ericsson, K. A. 1998. Basic capacities can be modified or circumvented by deliberate practice: A rejection of talent accounts of expert performance. Behavioral and Brain Sciences, 21: 413-414.

Feldman, M. S., \& March, J. G. 1981. Information in organizations as signal and symbol. Administrative Science Quarterly, 26: 171-186.

Fish, J., \& Scrivener, S. 1990. Amplifying the mind's eye: Sketching and visual cognition. Leonardo, 23: 117-126.

Fisher, G. 2012. Effectuation, causation, and bricolage: A behavioral comparison of emerging theories in entrepreneurship research. Entrepreneurship Theory and Practice, 36: 1019-1051.

Fiske, S. T., \& Taylor, S. E. 1991. Social cognition (2nd ed.). New York, NY: McGraw-Hill.

Fligstein, N. 1997. Social skill and institutional theory. The American Behavioral Scientist, 40: 397-405. 
Flynn, M., Dooley, L., O’Sullivan, D., \& Cormican, K. 2003. Idea management for organizational innovation. International Journal of Innovation Management, 7: 417-442.

Foo, M. D., Uy, M. A., \& Baron, R. A. 2009. How do feelings influence effort? An empirical study of entrepreneurs' affect and venture effort. The Journal of Applied Psychology, 94: 1086-1094.

Forisha, B. L. 1978. Creativity and imagery in men and women. Perceptual and Motor Skills, 47(3f): 12551264.

Fornell, C., \& Larcker, D. F. 1981. Evaluating structural equation models with unobservable variables and measurement error. JMR, Journal of Marketing Research, 18: 39-50.

Foster, J. 2007. How to get ideas. San Francisco, CA: Berrett-Koehler Publishers.

Frith, C. D., \& Frith, U. 2006. The neural basis of mentalizing. Neuron, 50: 531-534.

Frith, C. D., \& Frith, U. 2008. Implicit and explicit processes in social cognition. Neuron, 60: 503-510.

Gaglio, C. M. 2004. The role of mental simulations and counterfactual thinking in the opportunity identification process. Entrepreneurship Theory and Practice, 28: 533-552.

Galinsky, A. D., Maddux, W. W., Gilin, D., \& White, J. B. 2008. Why it pays to get inside the head of your opponent: The differential effects of perspective taking and empathy in negotiations. Psychological Science, 19: 378-384.

Gallupe, R. B., Dennis, A. R., Cooper, W. H., Valacich, J. S., Bastianutti, L. M., \& Nunamaker, J. F. 1992. Electronic brainstorming and group size. Academy of Management Journal, 35: 350-369.

Gartner, W. B. 2016. Entrepreneurship as organizing. Cheltenham, U.K.: Edward Elgar.

Garud, R., \& Giuliani, A. P. 2013. A narrative perspective on entrepreneurial opportunities. Academy of Management Review, 38: 157-160.

Garud, R., Schildt, H. A., \& Lant, T. K. 2014. Entrepreneurial storytelling, future expectations, and the paradox of legitimacy. Organization Science, 25: 1479-1492.

Gemmell, R. M., Boland, R. J., \& Kolb, D. A. 2012. The sociocognitive dynamics of entrepreneurial ideation. Entrepreneurship Theory and Practice, 36: 1053-1073.

Gielnik, M. M., Frese, M., Graf, J. M., \& Kampschulte, A. 2012. Creativity in the opportunity identification process and the moderating effect of diversity of information. Journal of Business Venturing, 27: 559-576.

Gielnik, M. M., Frese, M., \& Stark, M. S. 2015. Planning and entrepreneurship. In M. D. Mumford \& M. Frese (Eds.),
The psychology of planning in organizations: Research and applications: 289-311. New York, NY: Routledge.

Gilbert, D. T. 1991. How mental systems believe. The American Psychologist, 46: 107-119.

Gilovich, T., \& Medvec, V. H. 1995. The experience of regret: What, when, and why. Psychological Review, 102: 379-395.

Gioia, D. A., \& Chittipeddi, K. 1991. Sensemaking and sensegiving in strategic change initiation. Strategic Management Journal, 12: 433-448.

Gioia, D. A., Corley, K. G., \& Fabbri, T. 2002. Revising the past (while thinking in the future perfect tense). Journal of Organizational Change Management, 15: 622-634.

Goldman, A. I. 2006. Simulating minds: The philosophy, psychology, and neuroscience of mindreading. New York, NY: Oxford University Press.

González, M. A., Campos, A., \& Pérez, M. J. 1997. Mental imagery and creative thinking. The Journal of Psychology, 131: 357-364.

Good, D. J., Lyddy, C. J., Glomb, T. M., Bono, J. E., Brown, K. W., Duffy, M. K., Baer, R. A., Brewer, J. A., \& Lazar, S. W. 2016. Contemplating mindfulness at work: An integrative review. Journal of Management, 42: 114-142.

Goodwin, C. J. 2009. Research in psychology: Methods and design. New York, NY: John Wiley \& Sons.

Gough, H. G. 1979. A creative personality scale for the Adjective Check List. Journal of Personality and Social Psychology, 37: 1398-1405.

Grant, A. M., \& Berry, J. W. 2011. The necessity of others is the mother of invention: Intrinsic and prosocial motivations, perspective taking, and creativity. Academy of Management Journal, 54: 73-96.

Grégoire, D. A., Barr, P. S., \& Shepherd, D. A. 2010. Cognitive processes of opportunity recognition: The role of structural alignment. Organization Science, 21: 413-431.

Grégoire, D. A., Corbett, A. C., \& McMullen, J. S. 2011. The cognitive perspective in entrepreneurship: An agenda for future research. Journal of Management Studies, 48: $1443-1477$.

Grégoire, D. A., \& Shepherd, D. A. 2012. Technologymarket combinations and the identification of entrepreneurial opportunities: An investigation of the opportunity-individual nexus. Academy of Management Journal, 55: 753-785.

Grossman, D. 1951. The construction and validation of two insight inventories. Journal of Consulting Psychology, 15: 109-114.

Gupta, V. K., Chiles, T. H., \& McMullen, J. S. 2016. A process perspective on evaluating and conducting 
effectual entrepreneurship research. Academy of Management Review, 41: 540-544.

Hayek, F. A. 1945. The use of knowledge in society. The American Economic Review, 35: 519-530.

Haynie, J. M., Shepherd, D. A., \& McMullen, J. S. 2009. An opportunity for me? The role of resources in opportunity evaluation decisions. Journal of Management Studies, 46: 337-361.

Hébert, R. F., \& Link, A. N. 1988. The entrepreneur: Mainstream views $\&$ radical critiques. New York, NY: Praeger.

Hébert, R. F., \& Link, A. N. 1989. In search of the meaning of entrepreneurship. Small Business Economics, 1: 39-49.

Heppner, P. P., \& Petersen, C. H. 1982. The development and implications of a personal problem-solving inventory. Journal of Counseling Psychology, 29: 6675 .

Hill, R. C., \& Levenhagen, M. 1995. Metaphors and mental models: Sensemaking and sensegiving in innovative and entrepreneurial activities. Journal of Management, 21: 1057-1074.

Hinkin, T. R. 1998. A brief tutorial on the development of measures for use in survey questionnaires. Organizational Research Methods, 1: 104-121.

Hmieleski, K. M., \& Corbett, A. C. 2008. The contrasting interaction effects of improvisational behavior with entrepreneurial self-efficacy on new venture performance and entrepreneur work satisfaction. Journal of Business Venturing, 23: 482-496.

Hopkins, R. 2016. Sartre. In A. Kind (Ed.), The Routledge handbook of philosophy of imagination: 82-93. New York, NY: Routledge.

Isaacson, W. 2011. Steve Jobs. New York, NY: Simon \& Schuster.

Isaksen, S. G., Dorval, K. B., \& Treffinger, D. J. 2011. Creative approaches to problem solving: A framework for innovation and change. Thousand Oaks, CA: SAGE.

James, K., Brodersen, M., \& Eisenberg, J. 2004. Workplace affect and workplace creativity: A review and preliminary model. Human Performance, 17: 169194.

Johnson, M. 1987. The body in the mind. Chicago, IL: University of Chicago Press.

Johnson, J. W. 2000. A heuristic method for estimating the relative weight of predictor variables in multiple regression. Multivariate Behavioral Research, 35: 1-19.

Johnson, J. W. 2004. Factors affecting relative weights: The influence of sampling and measurement error. Organizational Research Methods, 7: 283-299.
Judge, T. A., Heller, D., \& Mount, M. K. 2002. Five-factor model of personality and job satisfaction: A metaanalysis. The Journal of Applied Psychology, 87: 530-541.

Juhasz, J. B. 1972. An experimental study of imagining. Journal of Personality, 40: 588-600.

Kahneman, D., \& Tversky, A. 1982. The simulation heuristic. In D. Kahneman, P. Slovic, \& A. Tversky (Eds.), Judgment under uncertainty: Heuristics and biases: 201-208. New York, NY: Cambridge University Press.

Khatena, J. 1975. Vividness of imagery and creative self perceptions. Gifted Child Quarterly, 19: 33-37.

Kind, A. 2016. The Routledge handbook of philosophy of imagination. New York, NY: Routledge.

Kirton, M. 1976. Adaptors and innovators: A description and measure. The Journal of Applied Psychology, 61: 622-629.

Kirzner, I. M. 1973. Competition and entrepreneurship. Chicago, IL: University of Chicago Press.

Kirzner, I. M. 1979. Perception, opportunity, and profit. Chicago, IL: University of Chicago Press.

Kirzner, I. M. 1999. Creativity and/or alertness: A reconsideration of the Schumpeterian entrepreneur. The Review of Austrian Economics, 11: 5-17.

Klein, P. G. 2008. Opportunity discovery, entrepreneurial action, and economic organization. Strategic Entrepreneurship Journal, 2: 175-190.

Klotz, A. C., Hmieleski, K. M., Bradley, B. H., \& Busenitz, L. W. 2014. New venture teams: A review of the literature and roadmap for future research. Journal of Management, 40: 226-255.

Knight, F. H. 1921. Risk, uncertainty and profit. Boston, MA: Houghton Mifflin.

Koestler, A. 1964. The act of creation. New York, NY: Dell.

Kuratko, D. F., Hornsby, J. S., \& Hayton, J. 2015. Corporate entrepreneurship: The innovative challenge for a new global economic reality. Small Business Economics, 45: 245-253.

Lazear, E. P. 2004. Balanced skills and entrepreneurship. The American Economic Review, 94: 208-211.

LeBoutillier, N., \& Marks, D. F. 2003. Mental imagery and creativity: A meta-analytic review study. British Journal of Psychology, 94: 29-44.

Lechler, T. 2001. Social interaction: A determinant of entrepreneurial team venture success. Small Business Economics, 16: 263-278.

Lechmann, D. S., \& Schnabel, C. 2014. Are the selfemployed really jacks-of-all-trades? Testing the assumptions and implications of Lazear's theory of entrepreneurship with German data. Small Business Economics, 42: 59-76. 
Liedtka, J. 2014. Perspective: Linking design thinking with innovation outcomes through cognitive bias reduction. Journal of Product Innovation Management, 32: 925-938.

Long, C. P., Bendersky, C., \& Morrill, C. 2011. Fairness monitoring: Linking managerial controls and fairness judgments in organizations. Academy of Management Journal, 54: 1045-1068.

Lounsbury, M., \& Glynn, M. A. 2001. Cultural entrepreneurship: Stories, legitimacy, and the acquisition of resources. Strategic Management Journal, 22: 545-564.

MacKenzie, S. B., Podsakoff, P. M., \& Podsakoff, N. P. 2011. Construct measurement and validation procedures in MIS and behavioral research: Integrating new and existing techniques. Management Information Systems Quarterly, 35: 293-334.

Magnusson, P. R., Wästlund, E., \& Netz, J. 2014. Exploring users' appropriateness as a proxy for experts when screening new product/service ideas. Journal of Product Innovation Management, 33: 4-18.

Maier, N. R., \& Hoffman, L. R. 1964. Financial incentives and group decision in motivating change. The Journal of Social Psychology, 64: 369-378.

Markman, K. D., Gavanski, I., Sherman, S. J., \& McMullen, M. N. 1993. The mental simulation of better and worse possible worlds. Journal of Experimental Social Psychology, 29: 87-109.

Martell, R. F., Lane, D. M., \& Emrich, C. 1996. Male-female differences: A computer simulation. The American Psychologist, 51: 157-158.

Mathieu, J. E., Maynard, M. T., Rapp, T., \& Gilson, L. 2008. Team effectiveness 1997-2007: A review of recent advancements and a glimpse into the future. Journal of Management, 34: 410-476.

McCall, R. 2010. Critical conversations: Feedback as a stimulus to creativity in software design. Human Technology, 6: 11-37.

McKellar, P. 1957. Imagination and thinking. New York, NY: Basic Books.

McMullen, J. S. 2010. Perspective taking and the heterogeneity of the entrepreneurial imagination. Advances in Austrian Economics, 14: 113-143.

McMullen, J. S. 2015. Entrepreneurial judgment as empathic accuracy: A sequential decision-making approach to entrepreneurial action. Journal of Institutional Economics, 11: 1-31.

McMullen, J. S., \& Dimov, D. 2013. Time and the entrepreneurial journey: The problems and promise of studying entrepreneurship as a process. Journal of Management Studies, 50: 1481-1512.

McMullen, J. S., \& Kier, A. S. 2016. Trapped by the entrepreneurial mindset: Opportunity seeking and escalation of commitment in the Mount Everest disaster. Journal of Business Venturing, 31: 663-686.

McMullen, J. S., \& Kier, A. S. 2017. You don't have to be an entrepreneur to be entrepreneurial: The unique role of imaginativeness in new venture ideation. Business Horizons, 60: 455-462.

McMullen, J. S., \& Shepherd, D. A. 2006. Entrepreneurial action and the role of uncertainty in the theory of the entrepreneur. Academy of Management Review, 31: 132-152.

McMullen, J. S., Wood, M. S., \& Kier, A. S. 2016. An embedded agency approach to entrepreneurship public policy: Managerial position and politics in new venture location decisions. Academy of Management Perspectives, 30: 222-246.

Meadow, A., Parnes, S. J., \& Reese, H. 1959. Influence of instructions and problem sequence on a creative problem-solving test. The Journal of Applied Psychology, 43: 413-416.

Miller, D., \& Miller, I. 2017. Sources of entrepreneurial courage and imagination: Three perspectives, three contexts. Entrepreneurship Theory and Practice, 41: $667-675$.

Miller, T. L., Grimes, M. G., McMullen, J. S., \& Vogus, T. J. 2012. Venturing for others with heart and head: How compassion encourages social entrepreneurship. Academy of Management Review, 37: 616-640.

Mitchell, R. K., Busenitz, L. W., Bird, B., Marie, G. C., McMullen, J. S., Morse, E. A., \& Smith, J. B. 2007. The central question in entrepreneurial cognition research. Entrepreneurship Theory and Practice, 31: $1-27$.

Morris, M. H., Kuratko, D. F., \& Covin, J. G. 2011. Corporate entrepreneurship $\&$ innovation (3rd ed.). Mason, $\mathrm{OH}$ : South-Western/Cengage Learning.

Mueller, B. A., \& Shepherd, D. A. 2016. Making the most of failure experiences: Exploring the relationship between business failure and the identification of business opportunities. Entrepreneurship Theory and Practice, 40: 457-487.

Mumford, M. D., Mobley, M. I., Reiter-Palmon, R., Uhlman, C. E., \& Doares, L. M. 1991. Process analytic models of creative capacities. Creativity Research Journal, 4: 91-122.

Newell, A., \& Simon, H. A. 1972. Human problem solving. Englewood Cliffs, NJ: Prentice-Hall.

Norman, R. D., \& Ainsworth, P. 1954. The relationships among projection, empathy, reality and adjustment, operationally defined. Journal of Consulting Psychology, 18: 53-58.

Osborn, A. F. 1963. Applied imagination: Principles and procedures of creative problem solving. New York, NY: Scribner. 
Osterwalder, A., \& Pigneur, Y. 2010. Business model generation: A handbook for visionaries, game changers, and challengers. Hoboken, NJ: John Wiley \& Sons.

Paal, T., \& Bereczkei, T. 2007. Adult theory of mind, cooperation, Machiavellianism: The effect of mindreading on social relations. Personality and Individual Differences, 43: 541-551.

Paivio, A. 1971. Imagery and verbal processes. New York, NY: Holt.

Paivio, A. 1975. Neomentalism. Canadian Journal of Psychology, 29: 263-291.

Parnes, S. J. 1967. Creative behavior guidebook. New York, NY: Scribner.

Parnes, S. J., \& Meadow, A. 1959. Effects of "brainstorming" instructions on creative problem solving by trained and untrained subjects. Journal of Educational Psychology, 50: 171-176.

Parrott, C., \& Strongman, K. 1985. Utilization of visual imagery in creative performance. Journal of Mental Imagery, 9: 53-66.

Paulus, P. B., \& Nijstadm, B. A. 2003. Group creativity: Innovation through collaboration. New York, NY: Oxford University Press.

Penrose, E. T. 1959. The theory of the growth of the firm. New York, NY: John Wiley.

Pepper, S. C. 1942. World hypotheses. Berkeley, CA: University of California Press.

Perry-Smith, J. E., \& Mannucci, P. V. 2017. From creativity to innovation: The social network drivers of the four phases of the idea journey. Academy of Management Review, 42: 53-79.

Perry-Smith, J. E., \& Shalley, C. E. 2003. The social side of creativity: A static and dynamic social network perspective. Academy of Management Review, 28: 89-106.

Plucker, J. A., Beghetto, R. A., \& Dow, G. T. 2004. Why isn't creativity more important to educational psychologists? Potentials, pitfalls, and future directions in creativity research. Educational Psychologist, 39: 83-96.

Podsakoff, P. M., MacKenzie, S. B., Lee, J. Y., \& Podsakoff, N. P. 2003. Common method biases in behavioral research: A critical review of the literature and recommended remedies. The Journal of Applied Psychology, 88: 879-903.

Poetz, M. K., \& Schreier, M. 2012. The value of crowdsourcing: Can users really compete with professionals in generating new product ideas? Journal of Product Innovation Management, 29: 245-256.

Prandelli, E., Pasquini, M., \& Verona, G. 2016. In user's shoes: An experimental design on the role of perspective taking in discovering entrepreneurial opportunities. Journal of Business Venturing, 31: 287-301.

Puccio, G. J. 1999. Creative problem solving preferences: Their identification and implications. Creativity and Innovation Management, 8: 171-178.

Puccio, G. J., Mance, M., Switalski, L., \& Reali, P. D. 2012. Creativity rising: Creative thinking and creative problem solving in the 21st century. Buffalo, NY: ICSC Press.

Rauch, A., \& Frese, M. 2007. Let's put the person back into entrepreneurship research: A meta-analysis on the relationship between business owners' personality traits, business creation, and success. European Journal of Work and Organizational Psychology, 16: 353-385.

Rice, R., \& Rogers, E. 1980. Reinvention in the innovation process. Knowledge, 1: 499-514.

Richardson, A. 1969. Mental imagery. London, U.K.: Routledge, Kegan, Paul.

Ries, E. 2011. The lean startup: How today's entrepreneurs use continuous innovation to create radically successful businesses. New York, NY: Crown Business.

Roese, N. J. 1997. Counterfactual thinking. Psychological Bulletin, 121: 133-148.

Runco, M. A. 2004. Creativity. Annual Review of Psychology, 55: 657-687.

Runco, M. A., \& Chand, I. 1995. Cognition and creativity. Educational Psychology Review, 7: 243-267.

Salter, A., Wal, A. L., Criscuolo, P., \& Alexy, O. 2015. Open for ideation: Individual-level openness and idea generation in R\&D. Journal of Product Innovation Management, 32: 488-504.

Sandberg, W. R., \& Hofer, C. W. 1987. Improving new venture performance: The role of strategy, industry structure, and the entrepreneur. Journal of Business Venturing, 2: 5-28.

Sarasvathy, S. D. 2001. Causation and effectuation: Toward a theoretical shift from economic inevitability to entrepreneurial contingency. Academy of Management Review, 26: 243-263.

Sarasvathy, S. D., \& Dew, N. 2005. New market creation as transformation. Journal of Evolutionary Economics, 15: 533-565.

Say, J. B. 1880. A treatise on political economy; or the production, distribution, and consumption of wealth. McMaster University Archive for the History of Economic Thought (ed. 4, no. say1880), Hamilton, Ontario, Canada. Retrieved from https://socialsciences. mcmaster.ca/econ/ugcm/3ll3/say/treatise.pdf

Schmeidler, G. R. 1965. Visual imagery correlated to a measure of creativity. Journal of Consulting Psychology, 29: 78-80. 
Schumpeter, J. A. 1934. The theory of economic development: An inquiry into profits, capital, credit, interest, and the business cycle. Cambridge, MA: Harvard University Press.

Schumpeter, J. A. 1942. Capitalism, socialism and democracy. New York, NY: Harper \& Brothers.

Schutz, A. 1967. The phenomenology of the social world. Chicago, IL: Northwestern University Press.

Seelig, T. 2015. Insight out: Get ideas out of your head and into the world. New York, NY: HarperCollins.

Segal, Z. V., Williams, J. M. G., \& Teasdale, J. D. 2002. Mindfulness-based cognitive therapy for depression: A new approach to preventing relapse. New York, NY: Guilford.

Shackle, G. L. S. 1979. Imagination and the nature of choice. Edinburgh, U.K.: Edinburgh University Press.

Shane, S. 2000. Prior knowledge and the discovery of entrepreneurial opportunities. Organization Science, 11: 448-469.

Shane, S. 2012. Reflections of the 2010 AMR Decade Award:Delivering on the promise of entrepreneurship as a field of research. Academy of Management Review, 37: 10-20.

Shane, S., \& Nicolaou, N. 2015. Creative personality, opportunity recognition and the tendency to start businesses: A study of their genetic predispositions. Journal of Business Venturing, 30: 407-419.

Shane, S., \& Venkataraman, S. 2000. The promise of entrepreneurship as a field of research. Academy of Management Review, 25: 217-226.

Shaw, G. A., \& DeMers, S. T. 1986. The relationship of imagery to originality, flexibility and fluency in creative thinking. Journal of Mental Imagery, 10: 65-74.

Shepherd, D. A. 2011. Multilevel entrepreneurship research: Opportunities for studying entrepreneurial decision making. Journal of Management, 37: 412420.

Shepherd, D. A. 2015. Party on! A call for entrepreneurship research that is more interactive, activity based, cognitively hot, compassionate, and prosocial. Journal of Business Venturing, 30: 489-507.

Shepherd, D. A., \& DeTienne, D. R. 2005. Prior knowledge, potential financial reward, and opportunity identification. Entrepreneurship Theory and Practice, 29: 91-112.

Shepherd, D. A., Haynie, J. M., \& McMullen, J. S. 2012. Confirmatory search as a useful heuristic? Testing the veracity of entrepreneurial conjectures. Journal of Business Venturing, 27: 637-651.

Shepherd, D. A., McMullen, J. S., \& Jennings, P. D. 2007. The formation of opportunity beliefs: Overcoming ignorance and reducing doubt. Strategic Entrepreneurship Journal, 1: 75-95.
Shepherd, D. A., Williams, T. A., \& Patzelt, H. 2015. Thinking about entrepreneurial decision making review and research agenda. Journal of Management, 41: 11-46.

Smith, K. G., \& Di Gregorio, D. 2002. Bisociation, discovery, and the role of entrepreneurial action. In M. A. Hitt, R. D. Ireland, S. M. Camp, \& D. L. Secton (Eds.), Strategic entrepreneurship: Creating a new mindset: 129-150. Oxford, England: Blackwell Publishing Company.

Smolensky, P. 1988. On the proper treatment of connectionism. Behavioral and Brain Sciences, 11: 123.

Spiro, R. L., \& Weitz, B. A. 1990. Adaptive selling: Conceptualization, measurement, and nomological validity. JMR, Journal of Marketing Research, 27: 61-69.

Sternberg, R. J. 1985. Beyond IQ: A triarchic theory of intelligence. Cambridge, England: Cambridge University Press.

Sternberg, R. J., \& Lubart, T. I. 1999. The concept of creativity: Prospects and paradigms. In R. J. Sternberg (Ed.), Handbook of creativity: 3-15. New York, NY: Cambridge University Press.

Stinchfield, B. T., Nelson, R. E., \& Wood, M. S. 2013. Learning from Levi-Strauss' legacy: Art, craft, engineering, bricolage, and brokerage in entrepreneurship. Entrepreneurship Theory and Practice, 37: 889-921.

Suddaby, R., Bruton, G. D., \& Si, S. X. 2015. Entrepreneurship through a qualitative lens: Insights on the construction and/or discovery of entrepreneurial opportunity. Journal of Business Venturing, 30: 1-10.

Taylor, S. E., Pham, L. B., Rivkin, I. D., \& Armor, D. A. 1998. Harnessing the imagination: Mental simulation, selfregulation, and coping. The American Psychologist, 53: 429-439.

Taylor, S. E., \& Schneider, S. K. 1989. Coping and the simulation of events. Social Cognition, 7: 174-194.

Tellegen, A., \& Atkinson, G. 1974. Openness to absorbing and self-altering experiences ("absorption”), a trait related to hypnotic susceptibility. Journal of Abnormal Psychology, 83: 268-277.

Thomas, N. J. T. 1999. Are theories of imagery theories of imagination? An active perception approach to conscious mental content. Cognitive Science, 23: 207245.

Tonidandel, S., \& LeBreton, J. M. 2011. Relative importance analysis: A useful supplement to regression analysis. Journal of Business and Psychology, 26: $1-9$.

Tonidandel, S., \& LeBreton, J. M. 2015. RWA web: A free, comprehensive, web-based, and user-friendly tool for 
relative weight analyses. Journal of Business and Psychology, 30: 207-216.

Tonidandel, S., LeBreton, J. M., \& Johnson, J. W. 2009. Determining the statistical significance of relative weights. Psychological Methods, 14: 387-399.

Tversky, A., \& Kahneman, D. 1974. Judgment under uncertainty: Heuristics and biases. Science, 185: 11241131.

Unger, J. M., Rauch, A., Frese, M., \& Rosenbusch, N. 2011. Human capital and entrepreneurial success: A metaanalytical review. Journal of Business Venturing, 26: 341-358.

Valett, R. E. 1983. Strategies for developing creative imagination $\&$ thinking skills. Retrieved from http:// www.eric.ed.gov/PDFS/ED233533.pdf

Vance, A. 2015. Elon Musk: How the billionaire CEO of SpaceX and Tesla is shaping our future. New York, NY: HarperCollins.

van den Ende, J., Frederiksen, L., \& Prencipe, A. 2014. The front end of innovation: Organizing search for ideas. Journal of Product Innovation Management, 32: 482-487.

Vogel, P. 2016. From venture idea to venture opportunity. Entrepreneurship Theory and Practice, 41: 943-971.

Völlm, B. A., Taylor, A. N. W., Richardson, P., Corcoran, R., Stirling, J., McKie, S., Deakin, J. F. W., \& Elliott, R. 2006. Neuronal correlates of theory of mind and empathy: A functional magnetic resonance imaging study in a nonverbal task. NeuroImage, 29: 90-98.

Vygotsky, L. S. 1990. Imagination and creativity in childhood. Soviet Psychology, 28: 84-96.

Wagner, J. 2003. Testing Lazear's jack-of-all-trades view of entrepreneurship with German micro data. Applied Economics Letters, 10: 687-689.

Ward, T. B. 2004. Cognition, creativity, and entrepreneurship. Journal of Business Venturing, 19: 173188.

Weick, K. E. 1989. Theory construction as disciplined imagination. Academy of Management Review, 14: 516-531.

Weick, K. E. 1993. Organizational redesign as improvisation. In G. P. Huber \& W. H. Glick (Eds.), Organizational change and redesign: Ideas and insights for improving performance: 346-379. New York, NY: Oxford University Press.

Weick, K. E. 1995. Sensemaking in organizations. Thousand Oaks, CA: SAGE.
Weick, K. E. 2006. The role of imagination in the organizing of knowledge. European Journal of Information Systems, 15: 446-452.

West, G. P. 2007. Collective cognition: When entrepreneurial teams, not individuals, make decisions. Entrepreneurship Theory and Practice, 31: 77-102.

Westhead, P. 1995. Survival and employment growth contrasts between types of owner-managed high technology firms. Entrepreneurship Theory and Practice, 20: 5-27.

Wiklund, J., \& Shepherd, D. A. 2008. Portfolio entrepreneurship: Habitual and novice founders, new entry, and mode of organizing. Entrepreneurship Theory and Practice, 32: 701-725.

Witt, U. 2007. Firms as realizations of entrepreneurial visions. Journal of Management Studies, 44: 11251140.

Wolfberg, P. J. 2009. Play and imagination in children with autism (2nd ed.). New York, NY: Teachers College Press.

Wood, M. S., \& Williams, D. W. 2014. Opportunity evaluation as rule-based decision making. Journal of Management Studies, 51: 573-602.

Zhao, M., Hoeffler, S., \& Dahl, D. W. 2012. Imagination difficulty and new product evaluation. Journal of Product Innovation Management, 29(S1): 76-90.

Zhou, J., \& George, J. M. 2001. When job dissatisfaction leads to creativity: Encouraging the expression of voice. Academy of Management Journal, 44: 682696.

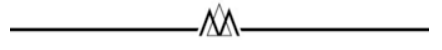

Alexander S. Kier (alex.kier@wsu.edu) is assistant professor of entrepreneurship at the Carson College of Business, Washington State University Vancouver. He received his PhD from Indiana University's Kelley School of Business. His research focuses on entrepreneurial imaginativeness, entrepreneurial cognition, and entrepreneurial escalation of commitment.

Jeffery S. McMullen (mcmullej@indiana.edu) is Dale M. Coleman Chair in Management and Professor of Entrepreneurship at Indiana University's Kelley School of Business. He received his $\mathrm{PhD}$ from University of Colorado's Leeds School of Business. His research focuses on entrepreneurial cognition, opportunity, and action in commercial entrepreneurship and social entrepreneurship.

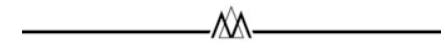




\section{APPENDIX A: SCENARIO DESCRIPTION}

\section{Part I}

Instructions: In this section, we would like to examine your ability to come up with new business ideas. After reading the passage below on a new emerging technology, please take a few minutes to list as many potential business ideas as possible based on this technology. The ideas you list may or may not be related to your current employment. Please note that it is extremely important for the validity of this survey that you take a few minutes and try to answer this question as fully as possible.

\section{Technology Description}

The technology is state-of-the-art facial recognition software that identifies a person by their face much like a fingerprint identifies a person by their finger (see Figure A1). The technology may not only revolutionize national surveillance and counter terrorism, but has promising commercial potential as well. For example, the facial recognition software would allow businesses to customize their marketing almost instantaneously by capturing information such as age, gender, and race of their customers.

\section{FIGURE A1}

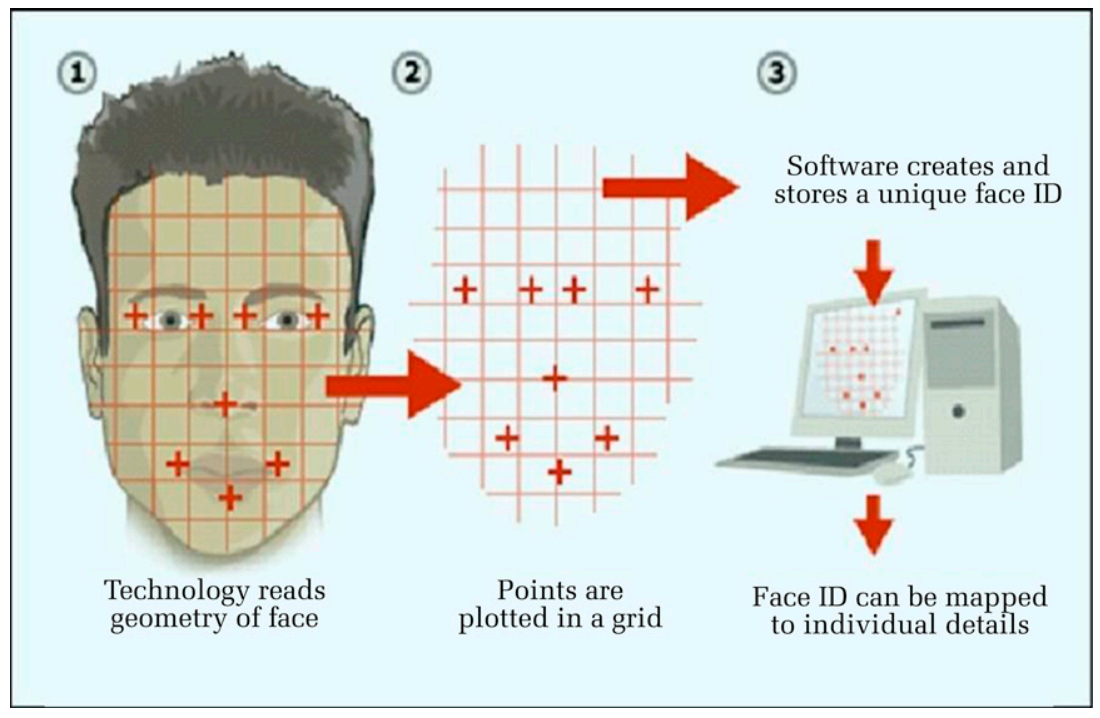

\section{Part II}

Instructions: Now that you have spent some time generating as many new business ideas as possible, please review your list of ideas and then select what you think is your best business idea based on facial recognition technology. Then write a short description of this idea in the space below. Please select only one idea.

\section{APPENDIX B: SCALE DEVELOPMENT AND VALIDATION}

TABLE B1

Results of Content Validity Assessment

\begin{tabular}{|c|c|c|c|c|c|c|}
\hline Form & \multicolumn{3}{|c|}{ Mean Ratings } & \multicolumn{3}{|c|}{ Standard Deviation of Ratings } \\
\hline Creative imaginativeness & 1.71 & 4.50 & 1.25 & 0.33 & 0.16 & 0.15 \\
\hline Social imaginativeness & 1.59 & 1.28 & 4.60 & 0.19 & 0.10 & 0.23 \\
\hline
\end{tabular}

Notes: Items were rated on a five-point Likert-type scale, ranging from 1 (not at all representative) to 5 (completely representative). PI = practical imaginativeness; $\mathrm{CI}=$ creative imaginativeness; SI = social imaginativeness. 
TABLE B2

Results of Confirmatory Factor Analysis for Imaginativeness Retained Items

\begin{tabular}{l}
\hline \multicolumn{1}{c}{ Items } \\
CFA Factor Loadings ${ }^{\mathbf{a}, \mathbf{b}}$ \\
\hline Creative Imaginativeness \\
1. I consider myself to be inventive. \\
2. I consider myself to be innovative. \\
3. I demonstrate originality in my work. \\
4. I like to create original work. \\
5. People say that I am artistic. \\
6. Being creative is a large part of who I am. \\
Social Imaginativeness \\
7. It is easy for me to see things from the other person's point of view. \\
8. I always make an effort to see the world through other people's eyes. \\
9. It is easy for me to understand why people feel the way they do. \\
10. I have a good sense for what other people are feeling. \\
11. I can read people's emotions just from their facial expressions. \\
12. I am good at reading people. \\
Practical Imaginativeness \\
13. I tend to be good at project management. \\
14. I can picture what the bottleneck of a system will be. \\
15. Before I face a new situation, I picture the issues I may encounter and plan accordingly. \\
16. I see connections between seemingly unrelated pieces of information. \\
17. Forming mental images helps me solve problems. \\
18. I extrapolate existing methods to solve new problems. \\
\hline
\end{tabular}

${ }^{\mathrm{a}} n=210 ; \chi^{2}=340.60, d f=132, p<.001 ; \mathrm{CFI}=0.91 ; \mathrm{SRMR}=0.05 ; \mathrm{RMSEA}=0.09$.

${ }^{\mathrm{b}}$ All factor loadings are completely standardized estimates and are significant at $p<.001$.

TABLE B3

Measurement Model Comparisons

\begin{tabular}{lrrrrr}
\hline \multicolumn{1}{c}{ Model } & \multicolumn{1}{c}{$\boldsymbol{\chi}^{\mathbf{2}}$} & $\boldsymbol{d} \boldsymbol{f}$ & CFI & SRMR & RMSEA \\
\hline One factor & $666.45^{* * *}$ & 135 & 0.78 & 0.08 & 0.14 \\
Two factor & $1188.18^{* * *}$ & 134 & 0.86 & 0.06 & 0.13 \\
Three factor & $340.60^{* * *}$ & 132 & 0.91 & 0.05 & 0.09 \\
Four factor & $884.88^{* * *}$ & 129 & 0.90 & 0.05 & 0.11 \\
\hline
\end{tabular}

Notes: $n=210 . \chi^{2}=$ chi-square statistic; $d f=$ degrees of freedom. $* * * p<.001$

TABLE B4

Discriminant Validity between Constructs

\begin{tabular}{|c|c|c|c|c|c|c|c|}
\hline & 1 & 2 & 3 & 4 & 5 & 6 & 7 \\
\hline 1. Practical imaginativeness & $(0.57)$ & & & & & & \\
\hline 2. Creative imaginativeness & 0.53 & $(0.72)$ & & & & & \\
\hline 4. Intuition & 0.04 & 0.05 & 0.07 & $(0.54)$ & & & \\
\hline 5. Creativity & 0.59 & 0.62 & 0.27 & 0.06 & $(0.62)$ & & \\
\hline 6. Perspective taking & 0.15 & 0.12 & 0.38 & 0.00 & 0.15 & (0.39) & \\
\hline
\end{tabular}

Note: Average variance extracted values appear in parentheses on the diagonal, and should be larger than the square of the inter-construct correlations in the corresponding row and column. 
Copyright of Academy of Management Journal is the property of Academy of Management and its content may not be copied or emailed to multiple sites or posted to a listserv without the copyright holder's express written permission. However, users may print, download, or email articles for individual use. 